\title{
Detoxification of toxin A and toxin B by copper ion-catalyzed oxidation in production of a toxoid-based vaccine against Clostridioides difficile
}

\author{
Aminzadeh, Aria; Tiwari, Manish Kumar; Mustapha, Srwa Satar Mamah; Navarrete, Sandra \\ Junquera; Henriksen, Anna Bielecka; Møller, Ian Max; Krogfelt, Karen Angeliki; Bjerrum, \\ Morten Jannik; Jørgensen, René \\ Published in: \\ Free Radical Biology \& Medicine
}

DOI:

10.1016/j.freeradbiomed.2020.08.021

Publication date:

2020

Document Version

Peer reviewed version

Citation for published version (APA):

Aminzadeh, A., Tiwari, M. K., Mustapha, S. S. M., Navarrete, S. J., Henriksen, A. B., Møller, I. M., Krogfelt, K. A., Bjerrum, M. J., \& Jørgensen, R. (2020). Detoxification of toxin A and toxin B by copper ion-catalyzed oxidation in production of a toxoid-based vaccine against Clostridioides difficile. Free Radical Biology \& Medicine, 2020(160), 433-446. https://doi.org/10.1016/j.freeradbiomed.2020.08.021

\section{General rights}

Copyright and moral rights for the publications made accessible in the public portal are retained by the authors and/or other copyright owners and it is a condition of accessing publications that users recognise and abide by the legal requirements associated with these rights.

- Users may download and print one copy of any publication from the public portal for the purpose of private study or research.

- You may not further distribute the material or use it for any profit-making activity or commercial gain.

- You may freely distribute the URL identifying the publication in the public portal.

Take down policy

If you believe that this document breaches copyright please contact rucforsk@kb.dk providing details, and we will remove access to the work immediately and investigate your claim. 


\section{Detoxification of Toxin A and Toxin B by copper ion-catalyzed}

2 oxidation in production of a toxoid-based vaccine against Clostridioides 3 difficile

5 Aria Aminzadeh ${ }^{1,2, \S}$, Manish Kumar Tiwari ${ }^{2, \S}$, Srwa Satar Mamah Mustapha ${ }^{1}$, Sandra Junquera

6 Navarrete $^{1}$, Anna Bielecka Henriksen ${ }^{1}$, Ian Max Møller ${ }^{3}$, Karen Angeliki Krogfelt ${ }^{4}$, Morten Jannik

$7 \quad$ Bjerrum $^{2, *}$, René Jørgensen ${ }^{1, *}$

$9 \quad{ }^{1}$ Statens Serum Institut, Department of Bacteria, Parasites and Fungi, Copenhagen, Denmark

$10 \quad{ }^{2}$ University of Copenhagen, Department of Chemistry, Copenhagen, Denmark

$11{ }^{3}$ Department of Molecular Biology and Genetics, Aarhus University, Forsøgsvej 1, DK-4200

12 Slagelse, Denmark

$13 \quad{ }^{4}$ Roskilde University, Molecular and Medical Biology, Roskilde Denmark

$15 *$ Correspondence to: mobj@chem.ku.dk/renj@ssi.dk

16 René Jørgensen

17 Statens Serum Institut, Department of Bacteria, Parasites and Fungi,

18 Artillerivej 5, 2300 Copenhagen S, Denmark

$19 \S$-These authors equally contributed to this work. 
Abstract

21 Clostridioides difficile infections (CDI) has emerged worldwide as a serious antimicrobial-resistant

22 healthcare-associated disease resulting in diarrhea and pseudomembranous colitis. The two cytotoxic proteins, toxin $A(T c d A)$ and toxin $B(T c d B)$ are the major virulence factor responsible for the disease symptoms. We examined time-dependent oxidative detoxification of TcdA and TcdB using different molar ratios of protein / $\mathrm{Cu}^{2+} / \mathrm{H}_{2} \mathrm{O}_{2}$. The $\mathrm{MCO}$ reaction in molar ratios of 1:60:1000 for protein / $\mathrm{Cu}^{2+} / \mathrm{H}_{2} \mathrm{O}_{2}$ at $\mathrm{pH} 4.5$ resulted in a significant $6 \log _{10}$ fold reduction in cytotoxicity after 120 -min incubation at $37^{\circ} \mathrm{C}$. Circular dichroism revealed that MCO- detoxified TcdA and TcdB had secondary and tertiary structural folds similar to the native proteins. The conservation of immunogenic epitopes of both proteins was tested using monoclonal antibodies in an ELISA, comparing our MCO-detoxification approach to a conventional formaldehyde-detoxification method.

31 The oxidative detoxification of TcdA and TcdB led to an average 2-fold reduction in antibody binding 32 relative to native proteins, whereas formaldehyde cross-linking resulted in 3-fold and 5-fold reductions, respectively. Finally, we show that mice immunized with a vaccine consisting of MCOdetoxified TcdA and TcdB were fully protected against disease symptoms and death following a $C$. difficile infection and elicited substantial serum IgG responses against both TcdA and TcdB. The results of this study present copper ion-catalyzed oxidative detoxification of toxic proteins as a method highly suitable for the rapid production of safe, immunogenic and irreversible toxoid antigens for future vaccine development and may have the potential for replacing cross-linking reagents like formaldehyde.

41 Keywords: Clostridioides difficile, CDI vaccine, Reactive oxygen species, Metal-catalyzed oxidation, Toxoid 


\section{Introduction}

C. difficile infection is the leading cause of healthcare-associated diarrhea and is responsible for around 453,000 incidences and 29,000 deaths every year in the United States alone [1]. More than $80 \%$ of CDI-related deaths occur in patients with age above 65 years leading to health care costs of approximately US\$ 6 billion per year in the United States [2]. This spore-forming, gram-positive anaerobic bacterium gives rise to a spectrum of disease symptoms, ranging from mild diarrhea to pseudomembranous colitis, toxic megacolon, and death [3,4]. The primary cause of pathogenicity by C. difficile is due to its clostridial toxins, TcdA and TcdB [5], which are large proteins with a molecular weight of $308 \mathrm{kDa}$ and $270 \mathrm{kDa}$, respectively, sharing structurally similar functional domains [6]. Both toxins are transferred into the host cell cytoplasm by receptor-mediated endocytosis where low $\mathrm{pH}$ in the endosome triggers conformational changes of the toxins activating the translocation of a catalytic domain across the membrane. Once inside the toxins inactivate Rho GTPases by attaching a glucose moiety to a catalytically important residue of the GTPase. This causes a degradation of the actin cytoskeleton leading to cell death [7]. Although there have been some contradicting reports of the individual potency and cytotoxic effects of each toxin [8-11] most in vivo studies suggest that they both contribute to disease during a natural infection $[8,12]$.

The primary treatment of CDI consists of narrow-spectrum antibiotics such as metronidazole, vancomycin, and fidaxomicin [13]. However, non-responders to metronidazole and vancomycin have been reported [14,15]. After treatment of the patient's first episode of CDI the risk of recurrence is 20-30\% and no approved antimicrobial treatment exists that provides a lower probability of secondary

CDI recurrence, which occurs in $40-60 \%$ of patients overcoming the first recurrence [16]. Recurrent $4 \mathrm{CDI}$ is likely a consequence of resident and long-lasting spores, reinfection, or the disruption of healthy microbiota due to the antibiotic treatment(s) $[16,17]$. The importance of a commensal gut 
microbiota against recurrent CDI is supported by successful reports of fecal transplantations, with disease resolution up to ca. $90 \%$ of patients $[18,19]$.

Studies in both animals and humans have shown that vaccination with detoxified TcdA and TcdB protects against CDI symptoms [20-23]. Thus, neutralization of TcdA and TcdB by toxinspecific antibodies is potentially an efficient method for preventing disease symptoms [24,25], and several toxoid-based vaccine candidates have made it to clinical trials [26-28]. Conventional detoxification methods such as cross-linking by formaldehyde have previously been used to detoxify toxins for vaccine production [29-31]. For instance, formaldehyde is successfully used in licensed toxoid-based vaccines against tetanus and diphtheria [32]. Unfortunately, formaldehyde-based detoxification has several disadvantages including i) slow and time-consuming [29], ii) risk of toxic reversibility over time $[33,34]$, iii) inherent carcinogenicity and toxicity associated with formaldehyde $[35,36]$ and finally, iv) suboptimal immunogenicity in some vaccines due to intra- and intermolecular cross-linked toxoids [37-39]. Thus, there is a need for identifying alternative approaches for rapid formation of safe, stable and highly immunogenic toxoids for future vaccines.

Oxidizing agents including divalent metal ions [40] and $\mathrm{H}_{2} \mathrm{O}_{2}$ [41] have long been used as antiseptics, disinfectants and for inactivation of virulence factors such as toxins [42]. Furthermore, it has been shown that the reactive oxygen species (ROS) produced via a $\mathrm{Fe}^{3+} / \mathrm{H}_{2} \mathrm{O}_{2} /$ EDTA system could effectively detoxify pertussis toxin. This method has produced a safe and irreversibly detoxified pertussis toxoid $[43,44]$, with higher epitope conservation than the formaldehyde-detoxified vaccine [38]. Despite the widespread knowledge, ROSs are widely considered agents of irreversible damage to biomolecules and tissues and the full advantage of these active oxygen species for contributing to medical advances has not been realized fully. In this study, using $\mathrm{pH}$-dependent conformational modulation of TcdA and TcdB combined with a controlled copper ion-catalyzed protein oxidation 
method developed by us previously $[45,46]$, we describe an efficient, permanent and safe method for producing highly immunogenic toxoids of TcdA and TcdB.

\section{Materials and Methods}

\subsection{Chemicals and reagents}

Stabilizer-free $30 \%$ hydrogen peroxide $\left(\mathrm{H}_{2} \mathrm{O}_{2} 30 \%\right)$ and copper(II)chloride dihydrate $\left(\mathrm{CuCl}_{2} \cdot 2\right.$ $\mathrm{H}_{2} \mathrm{O}$ ), was obtained from Merck Chemicals GmbH (Darmstadt, Germany). Whereas, iron(III) sulfate $\left(\mathrm{Fe}_{2}\left(\mathrm{SO}_{4}\right)_{3} \cdot 7 \mathrm{H}_{2} \mathrm{O}\right)$, Trizma base, crystal violet solution and SYPRO orange dye was purchased from Sigma-Aldrich (St. Louis, MO, USA). Formaldehyde (4\%, v/v) solution was obtained from VWR (Gliwice, Poland) and ethylenediaminetetraacetic acid disodium salt (2Na-EDTA) was obtained from BDH Ltd. (Poole, England). Monoclonal mouse anti-TcdA and anti-TcdB antibodies were purchased from tgcBIOMICS (Bingen, Germany). AP-conjugated goat anti-mouse $\operatorname{IgG}(\mathrm{H}+\mathrm{L})$ was purchased from Dako A/S (Glostrup, Denmark). HRP-conjugated rabbit anti-mouse $(\mathrm{H}+\mathrm{L})$ was purchased from Southern Biotech (Birmingham, AL, USA). TMB PLUS2 was obtained from Kem-En-Tec Diagnostics A/S (Taastrup, Denmark). Dulbecco's Modified Eagle Medium (DMEM) was obtained from ThermoFisher (Waltham, MA, USA). Tryptone and Yeast Extract were obtained from Formedium (Norfolk, UK). Tryptone, yeast extract, mannitol (TYM) consists of $24 \mathrm{~g} / \mathrm{L}$ tryptone, 12 $\mathrm{g} / \mathrm{L}$ yeast extract, $10 \mathrm{~g} / \mathrm{L}$ mannitol, $1 \mathrm{~g} / \mathrm{L}$ glycerol where tryptone, yeast extract, sodium thioglycolate (TYS) consists of $30 \mathrm{~g} / \mathrm{L}$ tryptone, $20 \mathrm{~g} / \mathrm{L}$ yeast extract, $1 \mathrm{~g} / \mathrm{L}$ sodium thioglycolate. HiTrap Q FF column (4 x 5 mL serially connected), MonoQ 10/100 GL column and HiPrep 16/60 Sephacryl S300 column were purchased from GE Healthcare Life Sciences (Pittsburgh, PA, USA). 


\subsection{Purification of $C$. difficile TedA and TedB}

TcdA and TcdB toxins from C. difficile Ribotype 027 (NCTC 13366) were purified using the dialysis bag method as described previously [47]. Briefly, an overnight anaerobic culture of $C$. 114 difficile in TYM medium was inoculated (1\%, v/v) into $2 \mathrm{~L}$ of sterile $0.9 \%$ saline in a dialysis bag suspended in $15 \mathrm{~L}$ of TYS. The media were pre-reduced with nitrogen and autoclaved before inoculation. Cultures were grown for 72 hours at $37{ }^{\circ} \mathrm{C}$, centrifuged at $18.500 \mathrm{xg}$ for $20 \mathrm{~min}$ at $4{ }^{\circ} \mathrm{C}$ and dialyzed using a Quattro 1000 Ultrafiltration/Diafiltration with a $50 \mathrm{kDa}$ cut-off membrane in 50 $\mathrm{mM}$ Tris- $\mathrm{HCl}(\mathrm{pH}$ 7.5). Separation of TcdA and TcdB from the dialyzed supernatants was achieved using a HiTrap Q FF anion-exchange column, integrated on a fast protein liquid chromatography (FPLC). The toxins were eluted with a linear 0 to $1 \mathrm{M} \mathrm{NaCl}$ gradient, with TcdA eluting at $150-200$ $\mathrm{mM} \mathrm{NaCl}$ and $\mathrm{TcdB}$ at $400-450 \mathrm{mM} \mathrm{NaCl}$. Fractions were visualized on SDS-PAGE and protein sizes corresponding to either TcdA or TcdB were pooled and further purified using a HiPrep 16/60 Sephacryl S-300 size-exclusion column. In the final step, a high-resolution anion-exchange MonoQ 10/100 GL column was used.

\subsection{Differential scanning fluorimetry (DSF)}

Using a 96-well plate (MicroAmp, applied biosystems, USA), $2 \mu \mathrm{L}$ of SYPRO Orange dye (62x concentrated stock) was mixed with $1.25 \mu \mathrm{M}$ TcdA or $0.8 \mu \mathrm{M}$ TcdB in individual $\mathrm{pH}$-adjusted buffers to a final volume of $25 \mu \mathrm{L}$. The plate was centrifuged for 1 min at $2300 \mathrm{x} g$ before placing it into the

130 ABI 7500 Real-Time Polymerase Chain Reaction machine. The temperature gradient was set to run 131 from 20 to $95{ }^{\circ} \mathrm{C}$ with an increase of $1{ }^{\circ} \mathrm{C} / \mathrm{min}$, as described previously [48]. The fluorescence signal 132 was recorded and the obtained data were analyzed and processed on Graphpad Prism software version 1338 (San Diego, CA, USA). 


\subsection{Circular dichroism (CD) spectroscopy}

136 Secondary and tertiary structural changes in TcdA and TcdB were probed using far-UV (200-260

$137 \mathrm{~nm})$ and near-UV (250-320 nm) CD spectroscopy. A Jasco J-815 spectropolarimeter equipped with

138 a Peltier-element-controlled thermostat was used for all studies. All CD measurements were

139 performed with a spectral bandwidth of $2 \mathrm{~nm}$ and a scanning speed of $50 \mathrm{~nm} \mathrm{~min}{ }^{-1}$. Far-UV

140 measurements were performed using a cell of $0.1-\mathrm{cm}$ path length and near-UV measurements were

141 performed using a cell of $1.0-\mathrm{cm}$ path length. The temperature stability studies were performed by

142 heating TcdA or TcdB to the desired temperature, incubating for 5 min before measuring the $\mathrm{CD}$

143 spectrum, followed by heating to the next temperature and measuring a new CD spectrum. The

144 studies monitoring the secondary/tertiary structure of the toxins/toxoids after metal-catalyzed

145 oxidation were measured at $25^{\circ} \mathrm{C}$. The final CD spectra were obtained by subtracting the spectrum

146 of the sample buffer from the mean sample spectrum of two individual scans using Jasco Spectra

147 Analysis software, with a Savitzky-Golay algorithm of convolution width 11 applied as described

148 previously [45,46]. Molar ellipticity ([0]) in units of mdeg $\mathrm{cm}^{2} \mathrm{dmol}^{-1}$ was calculated as

$$
[\theta]=\frac{\operatorname{mdeg} \cdot M_{w}}{10 \cdot L \cdot c}
$$

150 where $[\theta]$ is calculated molar ellipticity, mdeg is experimentally measured ellipticity in mdeg, $M_{w}$ is 151 protein molecular weight $(\mathrm{g} / \mathrm{mol}), L$ is the optical path length $(\mathrm{cm}), c$ is the protein concentration $152(\mathrm{mg} / \mathrm{ml})$. 
Inactivation of TcdA and TcdB was achieved by $\mathrm{Cu}^{2+} / \mathrm{H}_{2} \mathrm{O}_{2}$ mediated metal-catalyzed oxidation (MCO) as previously described [45,46]. Briefly, in a pilot experiment MCO reactions with varying $\mathrm{Cu}^{2+}(15,30$ and $37.5 \mu \mathrm{M})$ and $\mathrm{H}_{2} \mathrm{O}_{2}(50,250,500$ and $1000 \mu \mathrm{M})$ concentrations were set to oxidatively modify $\mathrm{TcdA}(0.5 \mu \mathrm{M})$ at four $\mathrm{pH}$ values $(4,4.5,5,7.5)$ for $2 \mathrm{~h}$ at $37{ }^{\circ} \mathrm{C}$ and the $\mathrm{MCO}$ reaction was terminated by adding an optimized $2 \mathrm{mM}$ EDTA [45,46] and incubation on ice (Supplementary Table S1). Protein concentrations were measured by direct absorbance at $280 \mathrm{~nm}$ using a NanoDrop ND-1000 spectrophotometer. All buffers consisted of $50 \mathrm{mM}$ Tris with $\mathrm{pH}$ adjusted using acetic acid. From the pilot experiment, the best condition showing the highest levels of TcdA inactivation was further subjected to time-dependence trials at four-time points $(30,60,90$, $120 \mathrm{~min}$ ) as shown in Supplementary Fig. S1. Around $3-4 \mu \mathrm{M}$ of the toxin was mixed with $\mathrm{pH}-$ adjusted MCO components (toxin: $\mathrm{Cu}^{2+}: \mathrm{H}_{2} \mathrm{O}_{2}$ ) in a molar ratio of 1:60:1000, which were the optimal conditions for the final preparation of the toxoids. The reaction mixtures were mixed gently and transferred to a $37^{\circ} \mathrm{C}$ heating block. Control samples were also prepared at each $\mathrm{pH}$ value without

$168 \mathrm{CuCl}_{2}$ and $\mathrm{H}_{2} \mathrm{O}_{2}$. Further control samples were prepared at $\mathrm{pH} 4.5$ and 7.5 each containing one component of the reaction system (Supplementary Fig. S2 and S3). All samples were either analyzed immediately or after being stored a maximum of $2 \mathrm{~h}$ on ice.

\subsection{In vitro cytotoxicity}

Cell toxicity of native and MCO-detoxified TcdA and TcdB was tested using Vero cell culture

$174\left(5 \times 10^{4}\right.$ cells/ mL DMEM) [49]. After adding $150 \mu \mathrm{L}$ Vero cell culture to each well in a 96-well microtiter plate the plates were incubated in a HeraCell $150 \mathrm{i} \mathrm{CO}$ incubator at $36.5{ }^{\circ} \mathrm{C}$ and $5 \% \mathrm{CO}_{2}$ for $24 \mathrm{~h}$ prior to cytotoxicity testing. Native toxin and/or MCO-detoxified samples $(10 \mu \mathrm{L})$ were 
added to the first well in each row, followed by serial dilution. After $48 \mathrm{~h}$ of incubation at $36.5^{\circ} \mathrm{C}$ the level of cell rounding was assessed by visual inspection using a microscope. To further verify the visual assessment the plates were emptied for media and washed twice with $200 \mu \mathrm{L} /$ well PBS buffer. After washing, $200 \mu \mathrm{L} /$ well (4\%,v/v) formaldehyde was added and incubated at room temperature for $10 \mathrm{~min}$, followed by another washing step. Finally, the fixed cells inside the wells were stained using $0.1 \%$ crystal violet $(200 \mu \mathrm{L} /$ well), placed at room temperature for $10 \mathrm{~min}$ and washed gently with deionized water. Stained plates were photographed using a Bio-Rad Gel Doc Imager and qualitatively inspected.

\subsection{SDS-PAGE and Western Blot analysis}

TcdA and TcdB samples were visualized by reducing SDS-PAGE using TGX Stain-free ${ }^{\mathrm{TM}}$ mini-protein gels (Bio-Rad, Hercules, CA, USA). Fifteen $\mu \mathrm{L}$ sample $(0.5-1 \mu \mathrm{M} /$ well) was mixed with $5 \mu \mathrm{L}$ of $2 \mathrm{x}$ Laemmli Sample Buffer (Bio-Rad, USA), and incubated for $20 \mathrm{~min}$ at room temperature. Electrophoresis was carried out using TGS SDS Buffer (Bio-Rad, USA) for 30 min at $200 \mathrm{~V}, 500$ mA. Bio-Rad Precision Plus Protein Standard ( $4 \mu \mathrm{L} /$ well) was used as a molecular weight marker.

For Western Blot analysis, SDS-PAGE gel bands were transferred to a Trans-Blot Turbo 0.2 $\mu \mathrm{m}$ nitrocellulose membrane (Bio-Rad, USA) using electroblotting on a Bio-Rad Trans-Blot Turbo Transfer System for $7 \mathrm{~min}$ at $25 \mathrm{~V}, 2.5 \mathrm{~A}$. Subsequently, the nitrocellulose membrane was blocked with $5 \% \mathrm{w} / \mathrm{v}$ skim milk/TBS buffer for $30 \mathrm{~min}$ at $37^{\circ} \mathrm{C}$ with shaking, and thereafter washed $3 \times 5 \mathrm{~min}$. in TBS at $37^{\circ} \mathrm{C}$ with shaking. After washing, the membrane was incubated for $1 \mathrm{~h}$ at $37^{\circ} \mathrm{C}$ with mouse anti-TcdA or anti-TcdB antibodies diluted 1:100,000 in skim milk/TBS. Another washing step was performed, where after the blots were incubated for $1 \mathrm{~h}$ at $37^{\circ} \mathrm{C}$ with goat anti-mouse APconjugated antibody diluted 1:1000 in skim milk/TBS, followed by a final washing step. For 
visualization of antibody binding, SigmaFast BCIP/NBT tablets (Sigma-Aldrich, St. Louis, MO, 201 USA) were used.

\subsection{Stability study}

Native and MCO-detoxified TcdA and TcdB samples were incubated at $-20{ }^{\circ} \mathrm{C}, 4{ }^{\circ} \mathrm{C}$ and $25^{\circ} \mathrm{C}$ for 26 or 28 days. Detoxified TcdA was kept at $\mathrm{pH} 4.5$ during storage, whereas detoxified TcdB was adjusted to $\mathrm{pH} 7.5$ for storage. Cytotoxicity was measured for all samples using Vero cells. Furthermore, secondary structure was analyzed for all samples before and after incubation at the various temperatures using far-UV CD at $200-260 \mathrm{~nm}$.

\subsection{Epitope recognition study}

Polystyrene MaxiSorp microtiter plates (Nunc) were coated with $100 \mu 1$ of either $1 \mu \mathrm{g} / \mathrm{ml}$ native

212 or detoxified TcdA and TcdB, respectively, in $0.05 \mathrm{M} \mathrm{Na}_{2} \mathrm{CO}_{3}, 0.05 \mathrm{M} \mathrm{NaHCO}_{3}(\mathrm{pH} 9.6)$ and 213 incubated overnight at $5{ }^{\circ} \mathrm{C}$. The next day, wells were blocked with $300 \mu$ of $1 \%(\mathrm{w} / \mathrm{v}) \mathrm{BSA}$ in PBS$2140.05 \%(\mathrm{v} / \mathrm{v})$ Tween $(\mathrm{pH} 7.4)$ and incubated for $2 \mathrm{~h}$ at $37^{\circ} \mathrm{C}$. One hundred $\mu$ of serially diluted 215 monoclonal antibody (1:4 in 1\% BSA in PBS- $0.05 \%$ Tween) was added to each well in triplicates 216 and incubated for $1 \mathrm{~h}$ at $37^{\circ} \mathrm{C}$. HRP-conjugated rabbit anti-mouse IgG diluted 1:5000 in $100 \mu \mathrm{L}$ of 217 1\% BSA in PBS- $0.05 \%$ Tween was added to each well, followed by incubation for $1 \mathrm{~h}$ at $37{ }^{\circ} \mathrm{C}$. 218 Antibody binding was visualized by the addition of $100 \mu \mathrm{L}$ TMB PLUS2 substrate and incubation at 219 room temperature for $15 \mathrm{~min}$, and the reaction was stopped by adding $50 \mu \mathrm{L}$ of $0.2 \mathrm{M} \mathrm{H}_{2} \mathrm{SO}_{4}$. 220 Absorbance was measured at $450 \mathrm{~nm}$ using a POLARstar OPTIMA microplate reader (BMG 
laboratories). Plates were washed 5 times with $250 \mu \mathrm{L}$ washing buffer (PBS-0.05\% Tween 20) between each step.

\subsection{Toxoid preparation for mouse challenge study}

The MCO-detoxified vaccine was prepared by individually mixing $11.2 \mu \mathrm{M}$ and $11.9 \mu \mathrm{M}$ TcdA and $\mathrm{TcdB}$, respectively, with $\mathrm{pH}$ 4.5-adjusted $\mathrm{MCO}$ components in a molar ratio of 1:60:1000 for toxin: $\mathrm{Cu}^{2+}: \mathrm{H}_{2} \mathrm{O}_{2}$ and incubated at $37^{\circ} \mathrm{C}$ for $2 \mathrm{~h}$. MCO reactions were terminated by adding EDTA to

a final concentration of $2 \mathrm{mM}$, adjusting $\mathrm{pH}$ to 7.5 and transferring the tubes to $4{ }^{\circ} \mathrm{C}$. The formaldehyde-detoxified vaccine was prepared by individually dialyzing $5.5 \mu \mathrm{M}$ TcdA and TcdB into $0.1 \mathrm{M}$ phosphate buffer, $\mathrm{pH} 7 \pm 0.2$ using $30 \mathrm{kDa}$ cut-off centrifugal filters (Amicon). Then formaldehyde was added to a final concentration of $0.45 \%(\mathrm{v} / \mathrm{v})$ and the samples incubated at room temperature $\left(25^{\circ} \mathrm{C}\right)$ for 7 days. Samples were then dialyzed against $0.1 \mathrm{M}$ phosphate, $0.1 \mathrm{M} \mathrm{NaCl}$, $233 \mathrm{pH} 7 \pm 0.2$ using $30 \mathrm{kDa}$ cut-off centrifugal filters at $4{ }^{\circ} \mathrm{C}$ to remove the formaldehyde. Formaldehyde was added to a final concentration of $0.016 \%(\mathrm{v} / \mathrm{v})$ after dialysis to prevent the reversion of toxicity, and samples were stored at $4{ }^{\circ} \mathrm{C}$. Each individual toxin from the MCO- and formaldehyde-detoxified samples were diluted to $0.2 \mathrm{mg} / \mathrm{ml}$ and mixed with aluminium hydroxide (Alhydrogel ${ }^{\circledR}$ ) to a final concentration of $2 \mathrm{mg} / \mathrm{ml}$ and incubated for $24 \mathrm{~h}$ at $4{ }^{\circ} \mathrm{C}$ shaking at $250 \mathrm{rpm}$. The next day, aluminium 238 hydroxide-adsorbed TcdA and TcdB samples were mixed in equal ratios of TcdA and TcdB, in a final 239 vaccine formulation consisting of $0.1 \mathrm{mg} / \mathrm{ml} \mathrm{TcdA}, 0.1 \mathrm{mg} / \mathrm{ml} \mathrm{TcdB}$ and $2 \mathrm{mg} / \mathrm{ml}$ aluminium 240 hydroxide. Each vaccine dose of $50 \mu \mathrm{L}$ contained $5 \mu \mathrm{g}$ TcdA and $5 \mu \mathrm{g}$ TcdB, detoxified with either 241 MCO or formaldehyde. 


\subsection{Mouse challenge model of CDI}

The experimental protocol for this animal study was approved by The Danish Experimental Animal Inspectorate (No. 2018-15-0201-01387), and all applicable national guidelines for the care and use of animals were followed. Female C57BL/6J-OlaHsd mice, 8- to -10 weeks old and weighing approximately $18 \mathrm{~g}$ (Envigo, UK) were housed in three groups of 8 per cage under similar conditions. Food (Teklad 2916 Global 16\% protein rodent diet, Envigo), bedding (Tapvei aspen), nesting material (Enviro-dri), cage enrichments (cardboard house, dried corn, peanuts, sunseed - given twice a week) were all irradiated before use. Food and water were given ad libitum. Housing was a Type III cage and washed prior to use. The experimental model used in this study was based on the model developed by Chen et al. [50] and Erikstrup et al. [51]. Mice were immunized with a $50 \mu \mathrm{L}$ vaccine dose two times, on days 0 and 21 by intramuscular injection. The animals received either a formulation with MCO-detoxified vaccine $(n=8)$, formaldehyde-detoxified vaccine $(n=8)$ or an aluminium hydroxide (mock) control $(n=8)$. Blood samples were collected on days $0,21,49$ and 60 . In order to establish CDI, the normal enteric microbiota was disrupted by pretreating the mice with an antimicrobial mixture in the drinking water, for 3 days starting on day 50 , containing kanamycin $(40 \mathrm{mg} / \mathrm{kg})$, gentamycin $(3.5 \mathrm{mg} / \mathrm{kg})$, colistin $(4.2 \mathrm{mg} / \mathrm{kg})$, metronidazole $(21.5 \mathrm{mg} / \mathrm{kg})$ and vancomycin $(4.5$ $\mathrm{mg} / \mathrm{kg}$ ). The concentration of the antimicrobial mixture was calculated based on the average weight of the mice and their expected water consumption. On day 53, the mice were switched back to regular 261 drinking water and on day 55 all mice were intraperitoneally injected with a $200 \mu \mathrm{L}$ single dose of 262 clindamycin $(25 \mathrm{mg} / \mathrm{kg})$. On day 56 , all mice were challenged with $250 \mu \mathrm{L}$ of $0.3 \times 10^{7}$ colony263 forming units (CFU) of vegetative C. difficile Ribotype 027 (NCTC 13366) by oral gavage. The mice 264 were monitored for signs of disease (diarrhea, wet tail, weight loss) and death. A clinical scoring system based on activity level, weight loss, changed breathing, appearance of eyes and fur was used at least 5 times per day with strict criteria to euthanize moribund animals. 


\subsection{Serum IgG measurements by ELISA}

Polystyrene MaxiSorp microtiter plates (Nunc, Denmark) were coated with $100 \mu 1$ of either 1

$\mu \mathrm{g} / \mathrm{ml} \mathrm{TcdA}$ or TcdB in $0.05 \mathrm{M} \mathrm{Na}_{2} \mathrm{CO}_{3}, 0.05 \mathrm{M} \mathrm{NaHCO}_{3} \mathrm{pH} 9.6$ and incubated overnight at $5{ }^{\circ} \mathrm{C}$.

The next day, wells were blocked with $300 \mu \mathrm{l}$ of $1 \%$ BSA in PBS pH 7.4 and incubated for $2 \mathrm{~h}$ at 37

${ }^{\circ} \mathrm{C}$. Each mouse serum was 3 -fold serially diluted in $0.5 \%$ BSA-PBS and $100 \mu 1$ was added to each

well in triplicates and incubated for $1 \mathrm{~h}$ at $37^{\circ} \mathrm{C}$. HRP-conjugated rabbit anti-mouse IgG diluted 1:5000 in $100 \mu \mathrm{L} 0.5 \%$ BSA-PBS was added to each well, followed by incubation for $1 \mathrm{~h}$ at $37{ }^{\circ} \mathrm{C}$.

The antibody binding was visualized by the addition of $100 \mu \mathrm{L}$ TMB PLUS2 substrate and incubation at room temperature up to $10 \mathrm{~min}$, and the reaction was stopped by adding $100 \mu \mathrm{L}$ of $0.2 \mathrm{M} \mathrm{H}_{2} \mathrm{SO}_{4}$. Absorbance was measured at $450 \mathrm{~nm}$ using a POLARstar OPTIMA microplate reader (BMG laboratories). Plates were washed 5 times with $250 \mu \mathrm{L}$ washing buffer (PBS, pH 7.4, containing $0.05 \%(\mathrm{v} / \mathrm{v})$ Tween 20$)$ between each step.

\subsection{Toxin Neutralization Assay (TNA)}

One hundred $\mu \mathrm{L}$ cell culture in DMEM was added to each well in a 96-well microtiter plate and 283 incubated in a HeraCell $150 \mathrm{i} \mathrm{CO}$ incubator at $36.5^{\circ} \mathrm{C}$ and $5 \% \mathrm{CO}_{2}$ for $24 \mathrm{~h}$ prior to testing. Titrations 284 of TcdA and TcdB were tested for the toxin concentration causing $50 \%$ rounding of cells $\left(\mathrm{TC}_{50}\right)$ prior to TNA studies. A concentration of $4 \mathrm{x} \mathrm{TC}_{50}$ for TcdA $(4 \mathrm{ng} / \mathrm{ml})$ or TcdB $(7 \rho g / \mathrm{ml})$ was pre-incubated with a 2-fold serial dilution of sera from immunized animals for 90 min at $36.5{ }^{\circ} \mathrm{C}$ with $5 \% \mathrm{CO}_{2}$ prior to their addition to the cell culture. One hundred $\mu \mathrm{L}$ of toxin-sera mixture was added to each well containing $100 \mu \mathrm{L}$ cell culture and the plates were incubated for $48 \mathrm{~h}$ at $36.5^{\circ} \mathrm{C}$ with $5 \% \mathrm{CO}_{2}$. Cell rounding was inspected as described in the "In vitro cytotoxicity" paragraph. 


\subsection{Statistical analysis}

DSF curves and all ELISA titers are presented as the mean of three individual replicates. All statistical analysis of the data was performed using GraphPad Prism 8 software. Unpaired Student's t-test was used to calculate p-values for IgG titers and mean relative weights, whereas Mantel-Cox log-rank test was conducted on the Kaplan-Meier survival curves. P-values $<0.05$ was taken as significant.

\section{Results}

\subsection{Native expression of TcdA and TcdB}

Native forms of TcdA and TcdB were expressed using the C. difficile Ribotype 027 strain 301 (NCTC 13366). Brain Heart Infusion (BHI) broth is generally used as a growth medium for C. difficile 302 for native toxin expression [52,53], however, we found that using a growth medium containing 303 tryptone, yeast extract and sodium thioglycolate (TYS) produced a higher yield of toxins compared 304 to BHI (Supplementary Fig. S4). After $72 \mathrm{~h}$ of incubation at $37{ }^{\circ} \mathrm{C}$ under anaerobic conditions, the 305 toxins were purified from the culture supernatant using FPLC chromatography. Purified TcdA and 306 TcdB were evaluated by SDS-PAGE and western blot (WB) analysis in a neutral and acidic buffer 307 respectively, to evaluate if the toxins were degraded under the harsher acidic conditions (Fig. 1A and

308 1B). SDS-PAGE and antibody recognition of the neutral and acidic stored toxins confirmed the 309 presence of intact protein bands for both TcdA and TcdB. 
A

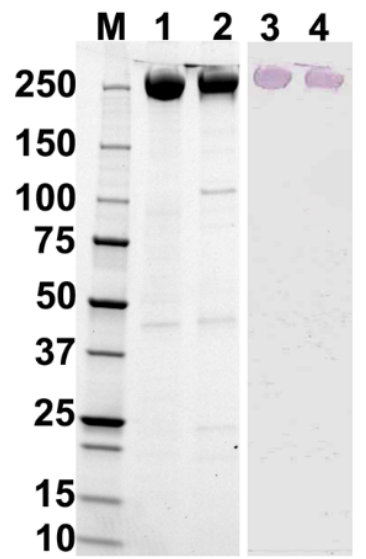

B

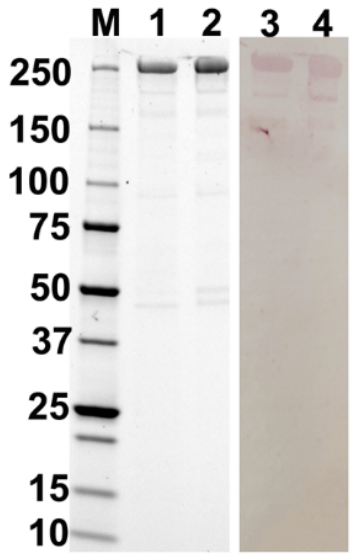

Figure 1. SDS-PAGE and WB analysis of native TedA and TcdB. TcdA $(0.9 \mu \mathrm{M})$ and $\operatorname{TcdB}(0.6 \mu \mathrm{M})$ were stored for 2 hours at $37^{\circ} \mathrm{C}$ in either neutral or acidic conditions prior to analysis. A: TcdA samples; lane M: molecular weight markers (kDa), lane 1: TcdA in pH 7.5 (protein stain), lane 2: TcdA in pH 4.5 (protein stain), lane 3: TcdA in pH 7.5 (western), lane 4: TcdA in pH 4.5 (western). B: TcdB samples; lane M: molecular weight markers ( $\mathrm{kDa}$ ), lane 1: TcdB in $\mathrm{pH} 7.5$ (protein stain), lane 2: TcdB in $\mathrm{pH} 4.5$ (protein stain), lane 3: TcdB in $\mathrm{pH} 7.5$ (western), lane 4: TcdB in $\mathrm{pH}$ 4.5 (western).

\subsection{Temperature stability of native purified TedA and TcdB}

The changes in the secondary structure of TcdA (Fig. 2A) and TcdB (Fig. 2B) with increasing temperature $\left(25\right.$ to $\left.80{ }^{\circ} \mathrm{C}\right)$ were monitored using circular dichroism (CD) in the $200-260 \mathrm{~nm}$ region.

315 TcdA shows well-defined far-UV CD spectra from $25{ }^{\circ} \mathrm{C}$ to $37{ }^{\circ} \mathrm{C}$ with similar spectral shapes and 316 two negative peaks at 208 and $218 \mathrm{~nm}$ (Fig. 2A). This indicates that the secondary structure of TcdA 317 is stable and largely intact during heating to $37^{\circ} \mathrm{C}$. However, at $45^{\circ} \mathrm{C}$ and $50{ }^{\circ} \mathrm{C}$ the spectra show a 318 slight change in the $208 \mathrm{~nm}$ region with a beginning loss of the negative peak at $208 \mathrm{~nm}$. By further

319 heating to $60{ }^{\circ} \mathrm{C}$, the loss of this characteristic peak is more severe, which is seen by the complete 320 loss of the negative peak at $208 \mathrm{~nm}$, indicating the unfolding of secondary protein structure. Heating 321 TcdA to $70{ }^{\circ} \mathrm{C}$ and then to $80{ }^{\circ} \mathrm{C}$, the far-UV CD spectra have now completely lost any well-defined 322 shape and the intensity of the CD spectra are significantly reduced overall, indicating denaturation of 
323 TcdA. TcdB also shows a well-defined far-UV CD spectrum during heating from $25^{\circ} \mathrm{C}$ to $37^{\circ} \mathrm{C}$ with

324 no significant changes in the spectrum, and the presence of two negative peaks at $208 \mathrm{~nm}$ and 218 $325 \mathrm{~nm}$ (Fig. 2B). At $45^{\circ} \mathrm{C}$ there is a slight increase in the intensity of the negative peak at $218 \mathrm{~nm}$, 326 showing the beginning of minor structural changes at this temperature. However, TcdB does not seem 327 to show significant spectral changes in the $208 \mathrm{~nm}$ region at $45^{\circ} \mathrm{C}$, unlike what is seen for TcdA (Fig. 328 2A), instead there are slight changes in the $218 \mathrm{~nm}$ region. Further heating to $50^{\circ} \mathrm{C}$ induces significant 329 changes in the secondary structure, which is seen by a more profound increase in the negative peak 330 at $218 \mathrm{~nm}$. This trend continues and increases during further heating to $60{ }^{\circ} \mathrm{C}$ and $70{ }^{\circ} \mathrm{C}$, but at $80{ }^{\circ} \mathrm{C}$ 331 the far-UV CD spectrum has changed drastically and completely lost the two negative peaks. At 80 $332{ }^{\circ} \mathrm{C}$, the $\mathrm{CD}$ spectrum shows a sharp rounded shape with a minimum of around $216 \mathrm{~nm}$, and a 333 significant increase is seen in the spectral intensity compared to the initial spectrum before heating.

A

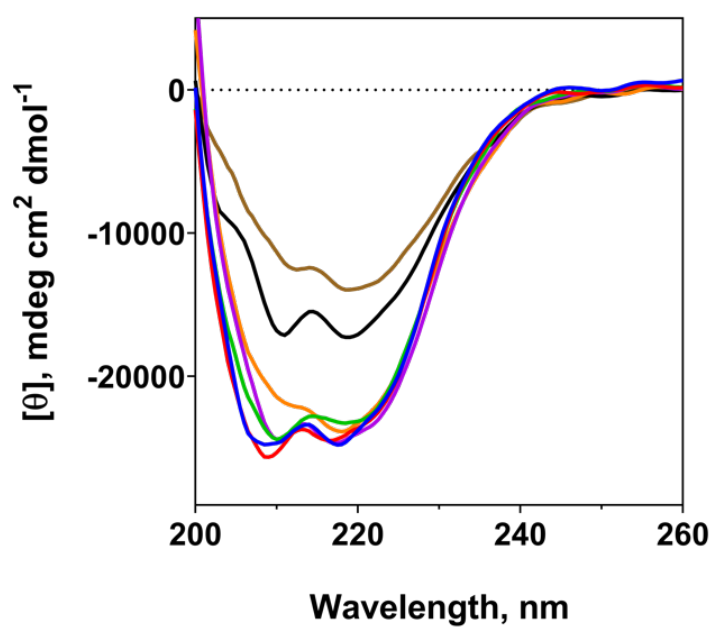

B

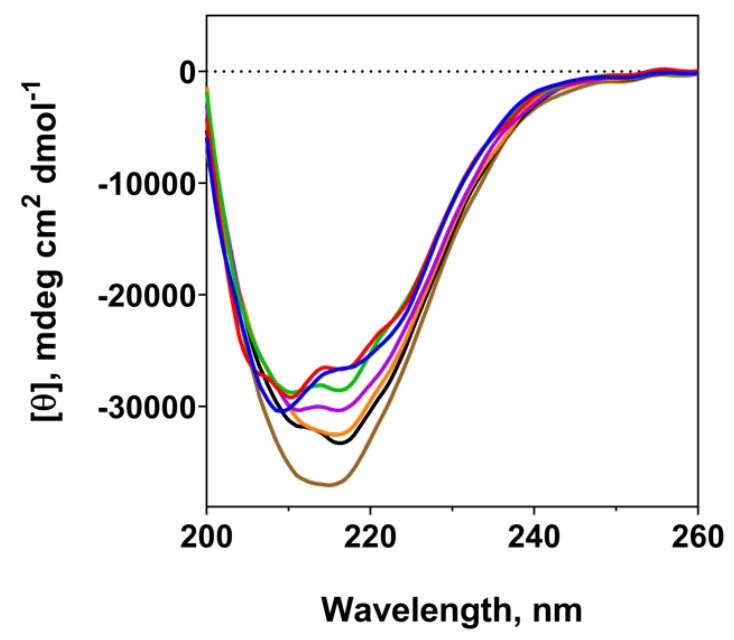

Figure 2. Effect of temperature on the secondary structure of TedA and TcdB. Circular dichroism analysis of TcdA and TcdB, showing the change in the secondary structure during heating. The samples are kept for 5 min at each temperature before measurement, and the measurements are cumulative. A: $0.65 \mu \mathrm{M}$ TcdA, B: $0.75 \mu \mathrm{M}$ TcdB. Blue: $25^{\circ} \mathrm{C}$, red: $37^{\circ} \mathrm{C}$, green: $45^{\circ} \mathrm{C}$, purple: $50^{\circ} \mathrm{C}$, orange: $60^{\circ} \mathrm{C}$, black: $70^{\circ} \mathrm{C}$, brown: $80^{\circ} \mathrm{C}$. 


\section{3 pH-induced thermostability changes}

Differential Scanning Fluorimetry (DSF) analysis was performed on TcdA (Fig. 3A) and TcdB (Fig. 3B), in temperature ranges from 25 to $95{ }^{\circ} \mathrm{C}$ with an increase of $1{ }^{\circ} \mathrm{C} / \mathrm{min}$. Both toxins were tested at five different $\mathrm{pH}$ conditions, ranging from $\mathrm{pH} 4$ to 7.5, and the resulting melting temperatures $339\left(T_{\mathrm{m}}\right)$ are listed in (Fig. 3C). The melting temperature $\left(T_{\mathrm{m}}\right)$ for TcdA at $\mathrm{pH} 7.5$ is $51.5^{\circ} \mathrm{C}$, which is in 340 alignment with the result obtained from the far-UV CD spectrum (Fig. 2A) showing initiation of 341 unfolding at $45-50{ }^{\circ} \mathrm{C}$. When lowering the $\mathrm{pH}$ to 6 and 5 respectively, no significant changes in the $342 T_{\mathrm{m}}$ values are observed. We only see a slight decrease of $1^{\circ} \mathrm{C}$ which lowers the $T_{\mathrm{m}}$ of $\mathrm{TcdA}$ in $\mathrm{pH} 6$ 343 and 5 to $50.5^{\circ} \mathrm{C}$, indicating that the thermal stability of TcdA is not significantly affected in the $\mathrm{pH}$ 344 range of 7.5 to 5 . However, by lowering the $\mathrm{pH}$ further to acidic levels of 4.5 and 4 , a significant 345 decrease can be seen in the $T_{\mathrm{m}}$ for TcdA. At $\mathrm{pH} 4.5$ there is a $4.5{ }^{\circ} \mathrm{C}$ decrease in the $T_{\mathrm{m}}$ reaching 47 $346{ }^{\circ} \mathrm{C}$, and at $\mathrm{pH} 4$ the decrease in $T_{\mathrm{m}}$ is as high as $9{ }^{\circ} \mathrm{C}$ reaching a melting temperature of only $42.5^{\circ} \mathrm{C}$. 347 TcdB has a slightly lower melting temperature at neutral $\mathrm{pH}$ than TcdA, with a $T_{\mathrm{m}}$ of $49^{\circ} \mathrm{C}$. This also 348 correlates with the data from the far-UV CD spectra (Fig. 2B), where the structural changes of TcdB 349 at $50{ }^{\circ} \mathrm{C}$ are more significant than for TcdA (Fig. 2A) confirming that TcdB has a lower melting 350 temperature. At $\mathrm{pH} 6$ the $T_{\mathrm{m}}$ is $47.5^{\circ} \mathrm{C}$, showing that $\mathrm{TcdB}$ is relatively stable when lowering the $\mathrm{pH}$ 351 from 7.5 to 6 , but not as stable as TcdA. However, when lowering the $\mathrm{pH}$ further to 5 , there is a 352 significant decrease in the $T_{\mathrm{m}}$ to $39^{\circ} \mathrm{C}$, which is much lower than the $T_{\mathrm{m}}$ of TcdA at $\mathrm{pH}$. When the $353 \mathrm{pH}$ is lowered to 4.5 the $T_{\mathrm{m}}$ of $\mathrm{TcdB}$ is further decreased by $7{ }^{\circ} \mathrm{C}$ reaching $32{ }^{\circ} \mathrm{C}$. At $\mathrm{pH} 4$, the $T_{\mathrm{m}}$ 354 cannot be calculated as the melting curve had no visible transition phase during heating. From the 355 DSF analysis (Fig. 3A and 3B), it is clear that at acidic pH around 4.5, TcdA and TcdB have lower 356 melting temperatures than at neutral $\mathrm{pH}$. 
A

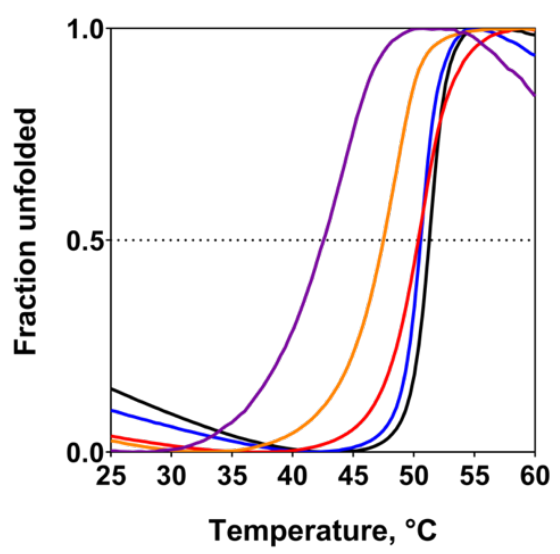

B

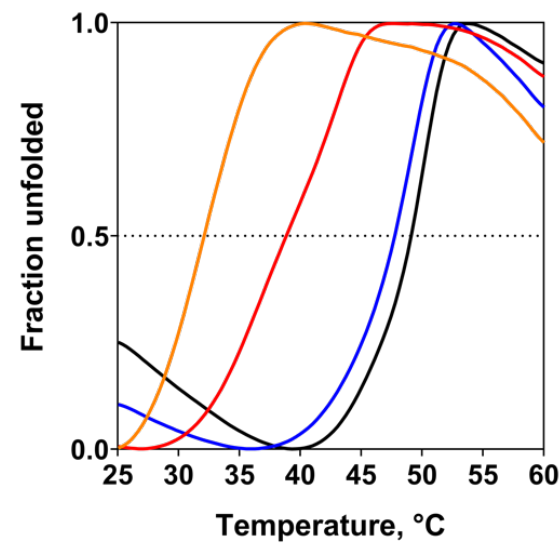

pH TedA TcdB

$\begin{array}{lll}4 & 42.5 & -\end{array}$

$\begin{array}{lll}4.5 & 47 & 32\end{array}$

$\begin{array}{lll}5 & 50.5 & 39\end{array}$

$\begin{array}{lll}6 & 50.5 & 47.5\end{array}$

$\begin{array}{lll}7.5 & 51.5 & 49\end{array}$

Figure 3. The effect of pH on the thermal stability of TcdA and TcdB. DSF was conducted using real-time PCR with a temperature gradient from 20 to $95{ }^{\circ} \mathrm{C}$ with an increase of $1{ }^{\circ} \mathrm{C} / \mathrm{min}$ (only 25 to $60{ }^{\circ} \mathrm{C}$ is shown). A: Each well contained $1.25 \mu \mathrm{M}$ of TcdA, pH-adjusted buffer, and $2 \mu \mathrm{l}$ of SYPRO orange dye (from 62x concentrated stock) in a final volume of $25 \mu$ l. B: Each well contained $0.8 \mu \mathrm{M}$ of TcdB, $\mathrm{pH}$-adjusted buffer, and $2 \mu 1$ of SYPRO orange dye (from 62x concentrated stock) in a final volume of $25 \mu$ l. Black: $50 \mathrm{mM}$ Tris- $\mathrm{HCl} \mathrm{pH} 7.5$, blue: $50 \mathrm{mM} \mathrm{Na-citrate} \mathrm{pH}$ 6, red: $50 \mathrm{mM} \mathrm{Na-acetate} \mathrm{pH}$ 5, orange: $50 \mathrm{mM} \mathrm{Na}$-acetate $\mathrm{pH} 4.5$, purple: $50 \mathrm{mM}$ Na-acetate $\mathrm{pH}$ 4. The melting temperatures $\left(T_{\mathrm{m}}\right)$ are given in ${ }^{\circ} \mathrm{C}$ on the right.

\subsection{Metal-catalyzed oxidation of TedA and TedB}

Different $\mathrm{pH}$ ranges and $\mathrm{MCO}$ components were tested in order to identify and optimize mild oxidative conditions for detoxification of TcdA and TcdB. A concentration of TcdA $(0.5 \mu \mathrm{M})$ at 37 ${ }^{\circ} \mathrm{C}$ was kept constant in the reaction mixture, and $\mathrm{MCO}$ treatment was tested at different $\mathrm{pH}$ values (4, 4.5, 5 and 7.5). The MCO components were also varied; $\mathrm{CuCl}_{2}(15$ to $37.5 \mu \mathrm{M})$ and $\mathrm{H}_{2} \mathrm{O}_{2}$ (50 to $1000 \mu \mathrm{M})$ as shown in Supplementary Table S1. All conditions were evaluated by SDS-PAGE, western blot analysis and Vero cell cytotoxicity assay (data not shown). These studies led to the optimal values of the MCO reaction components, which were determined to be molar ratios of 1:60:1000 for TcdA: $\mathrm{Cu}^{2+}: \mathrm{H}_{2} \mathrm{O}_{2}$, respectively, with a reaction $\mathrm{pH}$ of 4.5 and a concentration of TcdA of $0.5 \mu \mathrm{M}$. Then the optimal conditions such as molar ratios of oxidants, buffer and $\mathrm{pH}$ obtained on TcdA were transferred to TcdB in further studies. With this knowledge, we proceeded to test MCO 
on TcdA at $\mathrm{pH} 4.5$ and at $37^{\circ} \mathrm{C}$ with a range of different metal ions. All MCO samples were tested 370 for cytotoxicity (Supplementary Fig. S5) and the results are summarized in Table 1. Of all the tested 371 metal ions only $\mathrm{Cu}^{2+} / \mathrm{H}_{2} \mathrm{O}_{2}$ system was able to induce a significant inactivation of TcdA with our 372 MCO method, resulting in $6 \log _{10}$ reductions of cytotoxicity relative to native TcdA. A similar level 373 of TcdB inactivation was also achieved using $\mathrm{Cu}^{2+} / \mathrm{H}_{2} \mathrm{O}_{2}$ system at $\mathrm{pH} 4.5$ and $37^{\circ} \mathrm{C}$. The $\mathrm{Fe}^{2+} / \mathrm{H}_{2} \mathrm{O}_{2}$ 374 system and $\mathrm{Fe}^{3+} / \mathrm{H}_{2} \mathrm{O}_{2}$ systems were only capable of reducing the cytotoxicity by a negligible 50 -fold and 7-fold, respectively. None of the other metal ions had any significant effect on the cytotoxicity of TcdA as seen in Table 1. All conditions were evaluated by SDS-PAGE, western blot analysis and Vero cell cytotoxicity assay. TcdA and TcdB after MCO treatment at the optimal conditions were tested by cytotoxicity assay to determine the extent of reduction of cytotoxicity, in comparison to corresponding control samples (Supplementary Fig. S6 and S7) and summarized in Table 2.

The MCO detoxification of TcdA and TcdB at neutral $\mathrm{pH}$ using $\mathrm{Cu}^{2+}$ did not affect the cytotoxicity, whereas the same treatment at $\mathrm{pH} 4.5$ showed more than $6 \log _{10}$ fold reduction of the 382 cytotoxicity for both toxins. It was also tested whether the individual components of the MCO 383 reaction, such as $\mathrm{Cu}^{2+}, \mathrm{H}_{2} \mathrm{O}_{2}$ or the acidification in itself had any significant detoxifying effect on the 384 toxins (Supplementary Fig. S3), but the results showed that only the specific combination of $\mathrm{Cu}^{2+}$, $385 \mathrm{H}_{2} \mathrm{O}_{2}$, and acidic $\mathrm{pH}$ range (4.0 to 4.5) is able to produce highly detoxified TcdA and TcdB toxoids. 386 Finally, we studied the effect of different temperatures $\left(25\right.$ to $\left.37^{\circ} \mathrm{C}\right)$ and incubation times (30 to 120 $387 \mathrm{~min}$ ) on the efficacy of MCO inactivation (Supplementary Figs. S1 and S8). We found that the optimal 388 temperature and incubation time for effective inactivation of TcdA and TcdB is $37^{\circ} \mathrm{C}$ and $120 \mathrm{~min}$ 389 respectively. 
Table 1. Effect of various metal ions on the MCO detoxification of TcdA

\begin{tabular}{ccc} 
Metal salt & Metal-ion & Fold reduction in cytotoxicity \\
\hline $\mathrm{CuCl}_{2}$ & $\mathrm{Cu}^{2+}$ & $>1,000,000$ \\
$\mathrm{MgCl}_{2}$ & $\mathrm{Mg}^{2+}$ & 7 \\
$\mathrm{CoCl}_{2}$ & $\mathrm{Co}^{2+}$ & 7 \\
$\mathrm{MnCl}_{2}$ & $\mathrm{Mn}^{2+}$ & 7 \\
$\mathrm{Fe}_{2}\left(\mathrm{SO}_{4}\right)_{3}$ & $\mathrm{Fe}^{3+}$ & 7 \\
$\mathrm{FeSO}_{4}$ & $\mathrm{Fe}^{2+}$ & 50 \\
$\mathrm{CaCl}_{2}$ & $\mathrm{Ca}^{2+}$ & 7 \\
$\mathrm{LiCl}_{\mathrm{NiCl}}$ & $\mathrm{Li}^{+}$ & 7 \\
$\mathrm{AgNO}_{3}$ & $\mathrm{Ni}^{2+}$ & 7 \\
\hline
\end{tabular}

All MCO reactions were conducted at $\mathrm{pH} 4.5$ and each sample consisted of TcdA (1.2 $\mu \mathrm{M})$, a metal salt $(72 \mu \mathrm{M})$ and $\mathrm{H}_{2} \mathrm{O}_{2}(1200 \mu \mathrm{M})$ which were incubated for 2 hours at $37^{\circ} \mathrm{C}$ and measured for cytotoxicity on Vero cells (Fig. S5).

Table 2. Effect of $\mathrm{Cu}^{2+}$-catalyzed oxidation on the cytotoxicity of TcdA and TcdB

\begin{tabular}{|c|c|c|c|c|}
\hline Toxin & $\begin{array}{c}\text { Final toxin } \\
\text { concentration } \\
(\mu \mathrm{M})\end{array}$ & $\mathbf{p H}$ & $\frac{\text { Molar ratios }}{\left(\text { Toxin: } \mathrm{Cu}^{2+}: \mathrm{H}_{2} \mathrm{O}_{2}\right)}$ & Fold reduction in cytotoxicity \\
\hline TcdA native & 1.3 & 7.5 & $1: 0: 0$ & 1 \\
\hline TcdA native & 1.3 & 4.5 & $1: 0: 0$ & 50 \\
\hline TcdA MCO-detoxified & 1.3 & 4.5 & $1: 60: 1000$ & $>1,000,000$ \\
\hline TcdA MCO-detoxified & 1.3 & 7.5 & $1: 60: 1000$ & 5 \\
\hline TcdB native & 1.5 & 7.5 & $1: 0: 0$ & 1 \\
\hline TcdB native & 1.5 & 4.5 & $1: 0: 0$ & 350 \\
\hline TcdB MCO-detoxified & 1.5 & 4.5 & $1: 60: 1000$ & $>1,000,000$ \\
\hline TcdB MCO-detoxified & 1.5 & 7.5 & $1: 60: 1000$ & 5 \\
\hline
\end{tabular}

All MCO reactions were incubated for 2 hours at $37^{\circ} \mathrm{C}$ and measured for cytotoxicity on Vero cells (Figs. S6 and S7).

\subsection{MCO-induced structural changes}

The secondary structure of native and MCO detoxified TcdA and TcdB was monitored by far-

397 UV CD in the $200-260 \mathrm{~nm}$ region. Differences are observed in the $200-220 \mathrm{~nm}$ region between 398 MCO-detoxified and active TcdA (Fig. 4A). There is a slight loss of overall CD spectrum intensity 399 after MCO treatment, and the characteristic negative peak at $208 \mathrm{~nm}$ is lost, indicating some changes 400 in the $\alpha$-helical structure of TcdA after oxidation. The same trend is seen for TcdB with a loss of the 401 characteristic negative peak at $208 \mathrm{~nm}$ for the oxidized TcdB at $\mathrm{pH} 4.5$ (Fig. 5A). The CD results 
align with the DSF results, showing that the toxins are more prone to structural changes at $\mathrm{pH} 4.5$ 403 (Fig. 3A and 3B). However, as seen in Fig. 5A (red line), the CD spectrum of MCO-detoxified TcdB could be reversed to the native-like state by raising the $\mathrm{pH}$ to 7.5 after oxidation. Surprisingly, when 405 adjusting the $\mathrm{pH}$ of MCO-detoxified TcdA to 7.5, as we did for TcdB, we saw a significant reduction 406 of CD spectrum intensity, indicating a degree of precipitation caused by the $\mathrm{pH}$ change.

The tertiary structure of native and MCO-detoxified TcdA and TcdB were monitored by nearUV CD. The spectra for native and MCO-detoxified TcdA both show an overall similar shape with two negative peaks at 275 and $282 \mathrm{~nm}$ (Fig. 4B). The CD spectrum of MCO-detoxified TcdA, 410 however, has lower CD signal intensity compared to native TcdA, which could indicate that changes 411 of the aromatic residues have occurred or that the protein has slightly precipitated. The near-UV CD 412 spectrum of MCO-detoxified $\mathrm{TcdB}$ was monitored after readjusting $\mathrm{pH}$ to 7.5. The $\mathrm{CD}$ spectrum 413 shows a similar shape and finer features compared to native TcdB with two negative minima at 275 414 and $282 \mathrm{~nm}$ (Fig. 5B). Like TcdA, the MCO-detoxified TcdB CD spectrum has lower signal intensity 415 compared to the native TcdB spectrum.

Furthermore, to separate low $\mathrm{pH}$ and oxidative modification in the spectral changes of the CD, 417 we monitored far-UV CD (Supplementary Fig. S9) and near-UV (Supplementary Fig. S10) of TcdA 418 continuously during the $\mathrm{MCO}$ reaction at $\mathrm{pH} 4.5$. $\mathrm{CD}$ measurements were conducted every 3 min to 419 follow the progression of spectral changes. Interestingly, in the far-UV CD we see that already in the 420 first spectrum after initiating oxidation there is a change between native TcdA at $\mathrm{pH} 4.5$ to the MCO421 detoxified TcdA at $\mathrm{pH} 4.5$, meaning that MCO immediately causes more changes to the secondary 422 structure than $\mathrm{pH} 4.5$ alone. TcdA at $\mathrm{pH} 4.5$ and the MCO-detoxified TcdA at $\mathrm{pH} 4.5$, both show a 423 progression of spectral changes over time, however, the spectral changes happen faster and are more 424 extensive for the MCO-detoxified TcdA compared to TcdA at $\mathrm{pH}$ 4.5. The spectral changes progress 425 until reaching a plateau around the 15 min time point. Near-UV CD spectra were also monitored for 
426 the MCO reaction, and here we see an immediate change in the spectrum during the very first minutes 427 of the MCO reaction (Supplementary Fig. S10).

A

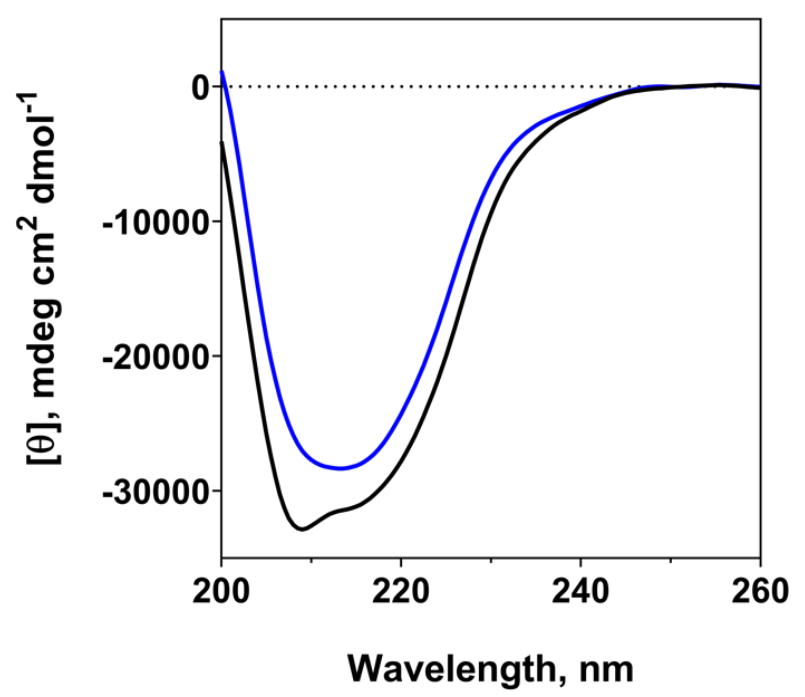

B

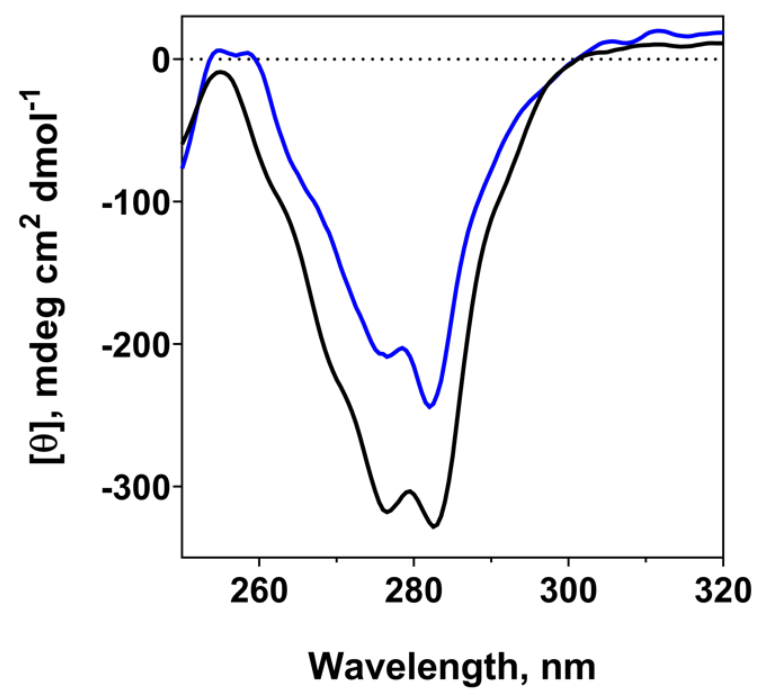

Figure 4. Circular dichroism analysis of native and MCO-detoxified TedA. All samples are shown as an average of duplicate measurements with the buffer spectrum (blank) subtracted. A: Far-UV CD spectra ranging from 200-260 $\mathrm{nm}$. The sample consisted of $1 \mu \mathrm{M}$ TcdA. B: Near-UV CD spectra ranging from $250-320 \mathrm{~nm}$. The sample consisted of $3.15 \mu \mathrm{M}$ TcdA. Black: native TcdA pH 7.5, blue: MCO-detoxified TcdA pH 4.5. 
A

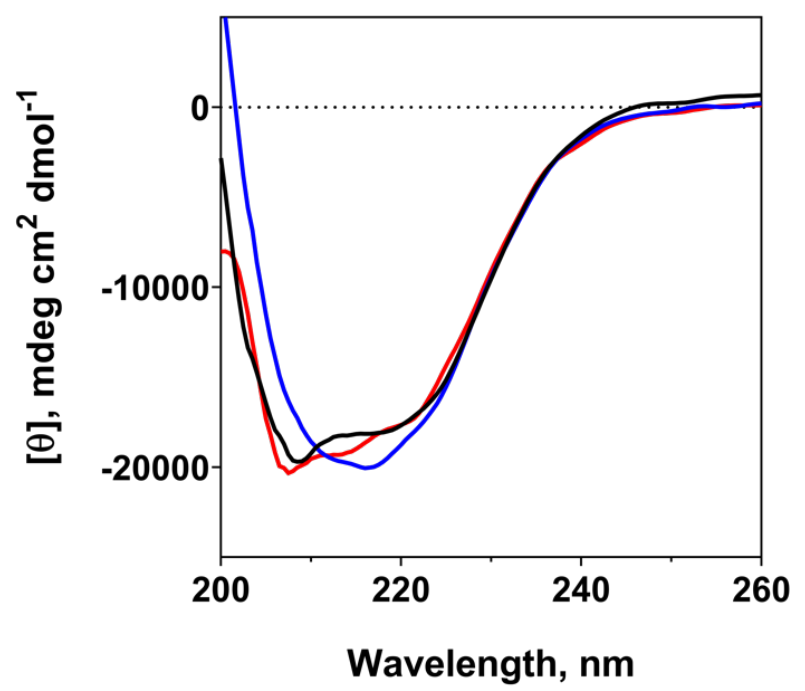

B

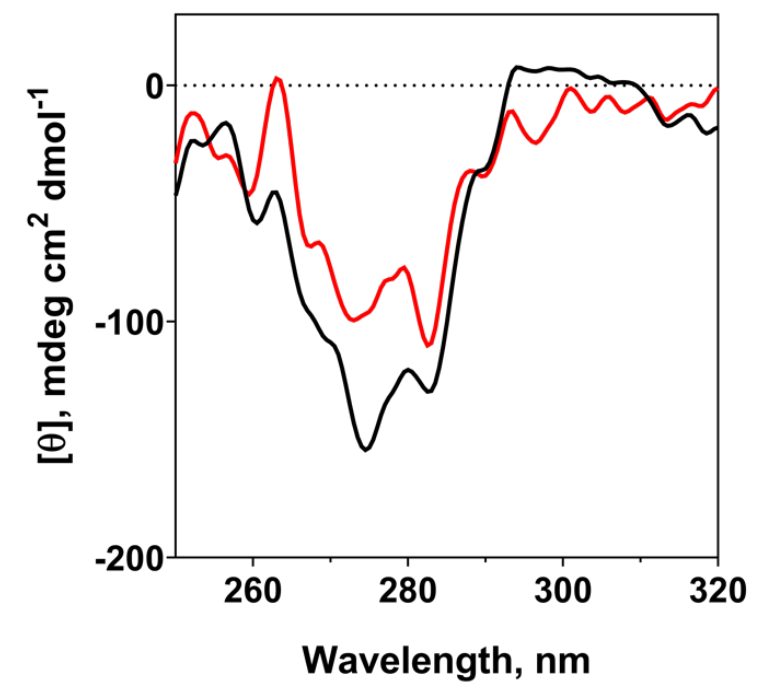

Figure 5. Circular dichroism analysis of native and MCO-detoxified TcdB. Far-UV CD samples are shown as an average of duplicate measurements with the buffer spectrum (blank) subtracted. Near-UV CD samples are shown as an average of 20 spectra with the buffer spectrum (blank) subtracted. A: Far-UV CD spectra ranging from $200-260$ $\mathrm{nm}$. The sample consisted of $0.75 \mu \mathrm{M}$ TcdB. B: Near-UV CD spectra ranging from $250-320 \mathrm{~nm}$. The sample consisted of $0.75 \mu \mathrm{M}$ TcdB. Black: native TcdB pH 7.5, blue: MCO-detoxified TcdB pH 4.5, red: MCO-detoxified TcdB readjusted to $\mathrm{pH} 7.5$.

\subsection{Epitope recognition after MCO detoxification}

The comparison between the binding of the mAbs to native and detoxified TcdA and TcdB are shown in Table 3 and 4, respectively. The oxidation of TcdA slightly affected the epitope binding to

433 the six different mAbs. The ranges of $\mathrm{mAb}$ binding are between $12 \%$ and $79 \%$ with an average of $43452 \%$, relative to the binding of the mAbs to native TcdA. Formaldehyde detoxification has a 435 significantly more deleterious effect on the TcdA epitopes, as the binding capacity of the mAbs is 436 between $8 \%$ and $38 \%$ with an average of $21 \%$. Detoxification of TcdB with either MCO or 437 formaldehyde follows a similar trend as TcdA, where MCO detoxification of TcdB leads to higher epitope recognition by the mAbs compared to formaldehyde. The binding efficacy of the five mAbs 
Table 3. Recognition of native and detoxified TcdA (TxdA) by monoclonal anti-TcdA antibodies

\begin{tabular}{cccc}
\hline mAb (target) & \multicolumn{3}{c}{ Toxin } \\
\cline { 2 - 4 } & TcdA-native & TcdA-MCO & TcdA-formaldehyde \\
\hline A-21 (C-terminal) & 1.00 & 0.43 & 0.38 \\
A-22 (C-terminal) & 1.00 & 0.47 & 0.09 \\
A-23 (C-terminal) & 1.00 & 0.79 & 0.37 \\
A-26 (C-terminal) & 1.00 & 0.5 & 0.08 \\
A-24 (N-terminal) & 1.00 & 0.12 & 0.24 \\
A-25 (N-terminal) & 1.00 & 0.79 & 0.09 \\
\hline
\end{tabular}

The recognition of MCO- or formaldehyde-detoxified TcdA by the mAbs is expressed as the ratio between the ELISA titer of the detoxified TcdA relative to the ELISA titer of native TcdA. The ELISA titer is defined as the endpoint titer, which is the highest dilution of mAb showing at least twice the $\mathrm{A}_{450}$ value of the blank wells. The ELISA titer of native TcdA is defined as 1.00. Formaldehyde-detoxification was conducted with $0.45 \%(\mathrm{v} / \mathrm{v})$ formaldehyde, $30 \mathrm{mM}$ lysine in $50 \mathrm{mM}$ Tris $\mathrm{pH} 7.5$ for 7 days at room temperature $\left(25^{\circ} \mathrm{C}\right)$.

\begin{tabular}{cccc}
\hline Table 4. Recognition of native and detoxified TcdB by monoclonal anti-TcdB antibodies \\
\hline mAb (target) & \multicolumn{2}{c}{ Toxin } & TcdB-formaldehyde \\
\cline { 2 - 4 } & TcdB-native & TedB-MCO & 0.37 \\
B-72 (C-terminal) & 1.00 & 0.65 & 0.1 \\
B-75 (C-terminal) & 1.00 & 0.57 & 0.38 \\
B-76 (C-terminal) & 1.00 & 0.57 & 0.69 \\
B-71 (N-terminal) & 1.00 & 0.51 & 0 \\
B-74 (N-terminal) & 1.00 & 0.55 & \\
\hline
\end{tabular}

The recognition of MCO or formaldehyde-detoxified TcdB by the mAbs is expressed as the ratio between the ELISA titer of the detoxified TcdB relative to the ELISA titer of native TcdB. The ELISA titer is defined as the endpoint titer, which is the highest dilution of mAb showing at least twice the A450 value of the blank wells. The ELISA titer of native TcdB is defined as 1.00 . Formaldehyde-detoxification was conducted with $0.45 \%(\mathrm{v} / \mathrm{v})$ formaldehyde, 30 $\mathrm{mM}$ lysine in $50 \mathrm{mM}$ Tris $\mathrm{pH} 7.5$ for 7 days at room temperature $\left(25^{\circ} \mathrm{C}\right)$.

\subsection{Stability}

Native and MCO-detoxified TcdA and TcdB were analyzed by far-UV CD and cytotoxicity testing after being stored for $26-28$ days at either $-20{ }^{\circ} \mathrm{C}, 4{ }^{\circ} \mathrm{C}$, and $25^{\circ} \mathrm{C}$. Neither native nor MCOdetoxified TcdA shows significant changes in the shapes of the CD spectra at day 28 compared to day 0 when stored at any of the different temperatures (Fig. 6A-C). However, at all storage conditions, there is a significant reduction of the overall spectral intensity after 28 days for both native and MCO- 
451 detoxified TcdA. TcdA samples (native and MCO-detoxified) show roughly the same level of spectral 452 intensity loss when stored at $-20{ }^{\circ} \mathrm{C}$ (Fig. 6A) and $4{ }^{\circ} \mathrm{C}$ (Fig. 6B) over 28 days, indicating that either 453 precipitation and/or degradation is occurring equally for both. Surprisingly, native TcdA stored at 25 $454{ }^{\circ} \mathrm{C}$ shows a more severe loss of CD spectrum intensity after 28 days, compared to the MCO-detoxified 455 TcdA sample at $25^{\circ} \mathrm{C}$.

456 MCO-detoxified TcdB also shows well-preserved CD spectral features after either 26 or 28 457 days of storage (Fig. 6D-F). Similar to the TcdA samples, the CD spectra for both native and MCO458 detoxified TcdB lose intensity overall during the storage period, likely caused by precipitation. 459 Interestingly, after storage at $25{ }^{\circ} \mathrm{C}$ for 26 days the $\mathrm{CD}$ spectrum for native $\mathrm{TcdB}$ has significantly 460 lower signal intensity compared to the MCO-detoxified TcdB CD spectrum, which is also seen for $461 \mathrm{TcdA}$ at $25^{\circ} \mathrm{C}$. None of the MCO-detoxified TcdA or TcdB samples show a reversal of cytotoxicity 462 during the storage period at any of the storage conditions. A small decrease in cytotoxicity is observed 463 during the storage period for both native and MCO- detoxified TcdA and TcdB, likely due to protein 464 precipitation as mentioned above. 
A

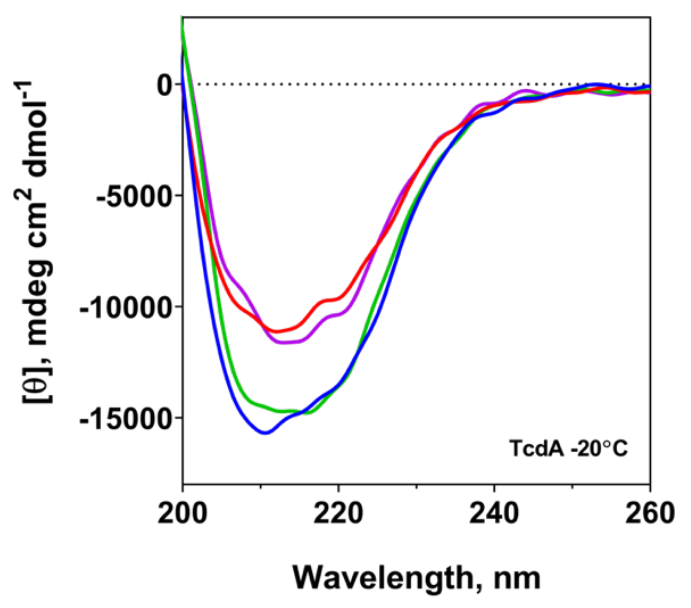

B

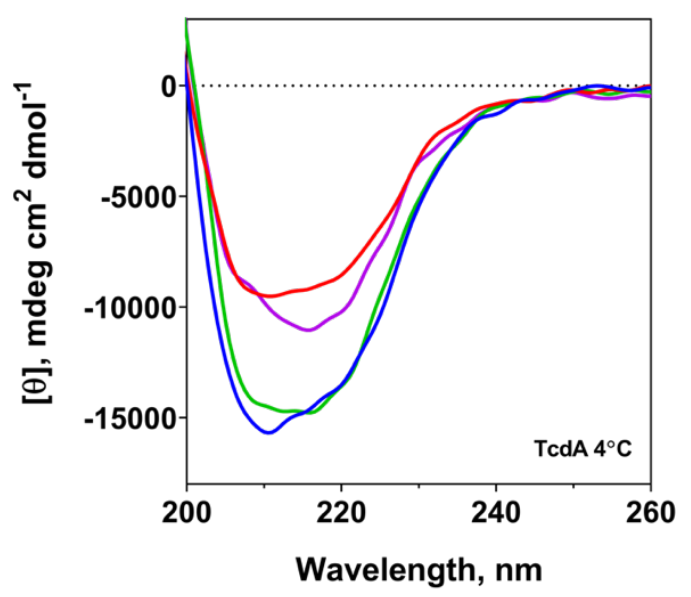

C

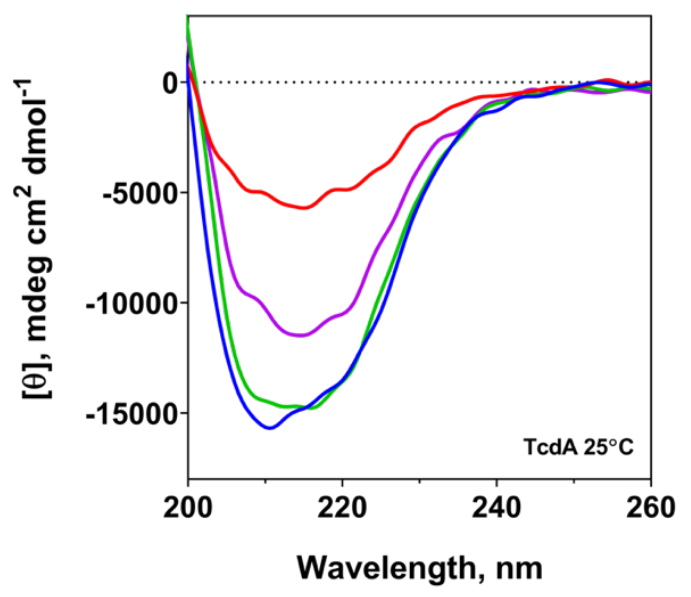

D

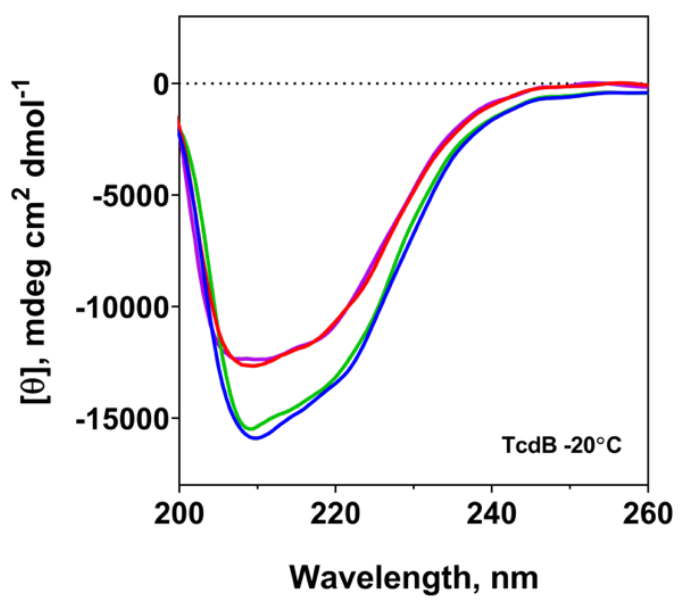

$\mathbf{E}$

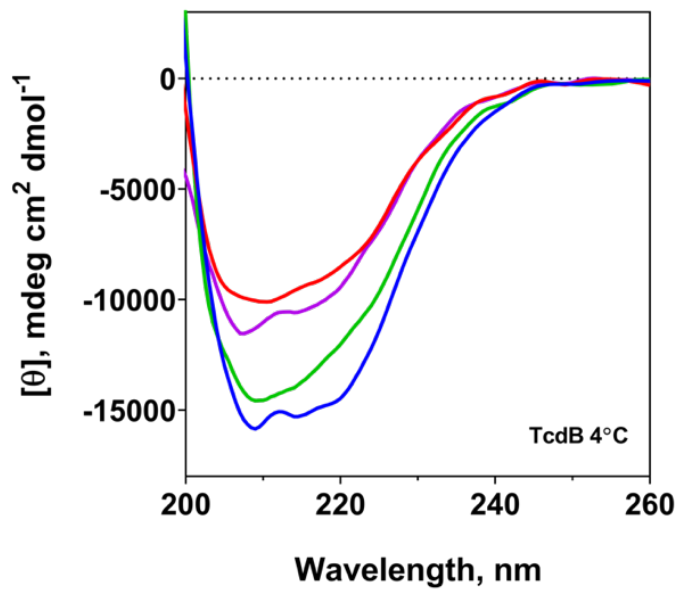

$\mathbf{F}$

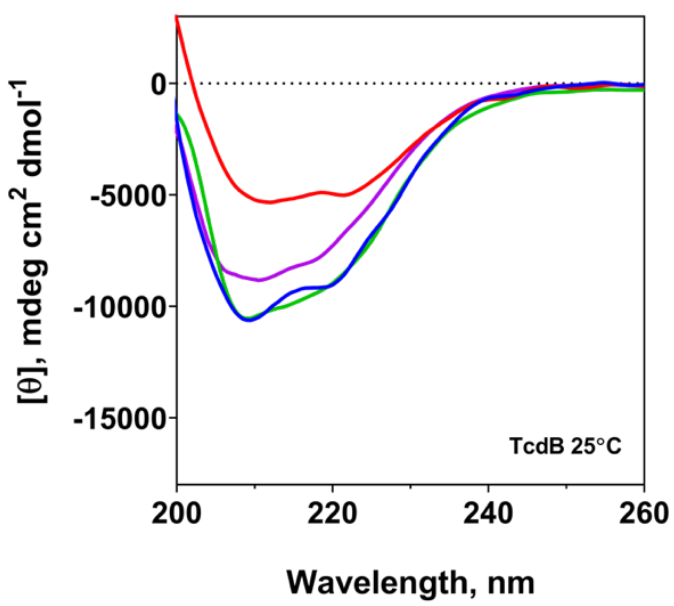

Figure 6. Long-term stability of native and MCO-detoxified TcdA and TcdB 
Samples were analyzed using far-UV CD $(200-260 \mathrm{~nm})$ on day 0 and again on either day 26 or 28 after storage at different temperatures. A: $0.6 \mu \mathrm{M}$ TcdA stored at $-20{ }^{\circ} \mathrm{C}$. B: $0.6 \mu \mathrm{M}$ TcdA stored at $4{ }^{\circ} \mathrm{C}$. C: $0.6 \mu \mathrm{M}$ TcdA stored at $25^{\circ} \mathrm{C}$. Blue: native TcdA day 0, red: native TcdA day 28 , green: MCO-detoxified TcdA day 0, purple: MCO-detoxified TcdA day 28. D: $0.7 \mu \mathrm{M} \mathrm{TcdB}$ stored at $-20^{\circ} \mathrm{C}$. E: $0.7 \mu \mathrm{M} \mathrm{TcdB}$ stored at $4{ }^{\circ} \mathrm{C}$. F: $0.7 \mu \mathrm{M} \mathrm{TcdB}$ stored at $25^{\circ} \mathrm{C}$. Blue: native TcdB day 0 , red: native TcdB day 26/28, green: MCO-detoxified TcdB day 0 , purple: MCO-detoxified TcdB day $26 / 28$.

\subsection{Immunogenicity and protective efficacy}

Both vaccinated groups showed no visible side effects from the vaccine injections. No swelling around the injection site and no change in either weight or temperature. The MCO-detoxified vaccine and the formaldehyde-detoxified vaccine both fully protected against the oral challenge given on day 56, and all mice survived (Fig. 7A) while showing no signs of CDI disease symptoms such as diarrhea or weight loss (Fig. 7B). On the other hand, the unvaccinated control mice all exhibited CDI symptoms and three out of the eight mice were moribund and had to be euthanized within 3 days post-challenge.

To assess the development of toxin-specific IgG and neutralizing antibody responses in mice, sera samples were collected on days $0,21,49$ and 60 after the primary immunization, and analyzed for levels of antibodies against native TcdA and TcdB, respectively, by ELISA and TNA. Immunization with both MCO- and formaldehyde-detoxified vaccine formulation elicited substantial anti-TcdA and anti-TcdB IgG responses, whereas control mice with mock injections had no detectable levels of antibodies in their sera (Fig. 7C and 7D). At day 60, mice immunized with the MCO-detoxified vaccine had mean anti-TcdA and anti-TcdB $\mathrm{EC}_{50}$ titers of around $4 \log _{10}$, whereas 482 the formaldehyde-detoxified vaccine-elicited mean anti-TcdA and anti-TcdB EC 50 titers of around $4834.2 \log _{10}$ and $4.17 \log _{10}$ respectively. There is no significant statistical difference between the mean anti-TcdA and $\mathrm{TcdB} \mathrm{EC}_{50}$ titers induced by the MCO- and formaldehyde-detoxified vaccines, respectively. The same serum samples were tested for toxin neutralizing activity on Vero cells, where 
486 native TcdA or TcdB were pre-incubated with serial dilutions of pooled sera for 90 min and added to 487 cells. The MCO- detoxified vaccine was less efficient at eliciting neutralizing antibodies against 488 TcdA compared to the formaldehyde-detoxified vaccine, with mean anti-TcdA neutralization titers at 489 day 60 of around 3100 and 7300 respectively (Fig. 7E). We could not detect any anti-TcdB 490 neutralizing antibodies in the sera of mice immunized with the MCO-detoxified vaccine, whereas the 491 formaldehyde-detoxified vaccine was able to elicit a low mean anti-TcdB neutralization titer of 492 around 600 at day 49 (Fig. 7F). 
A

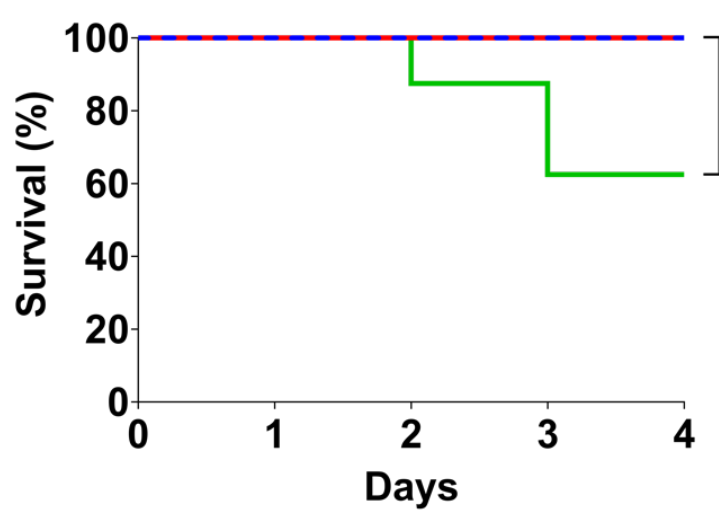

C

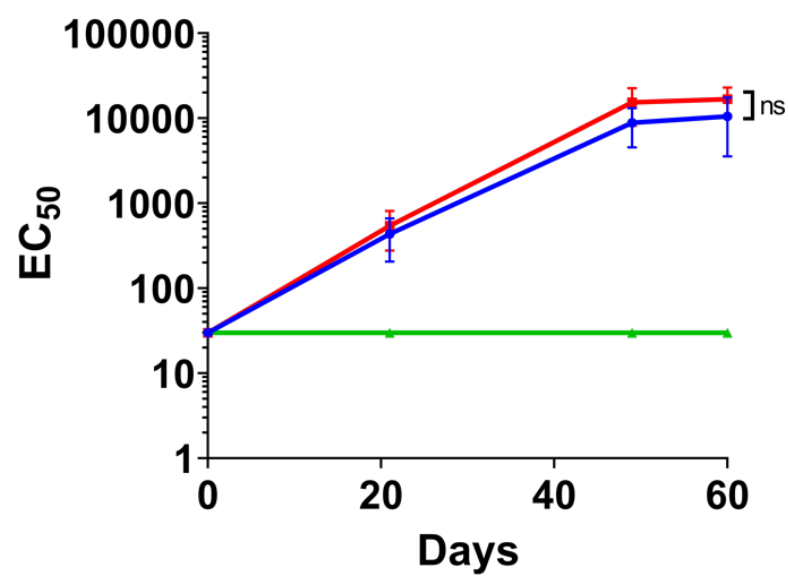

$\mathbf{E}$

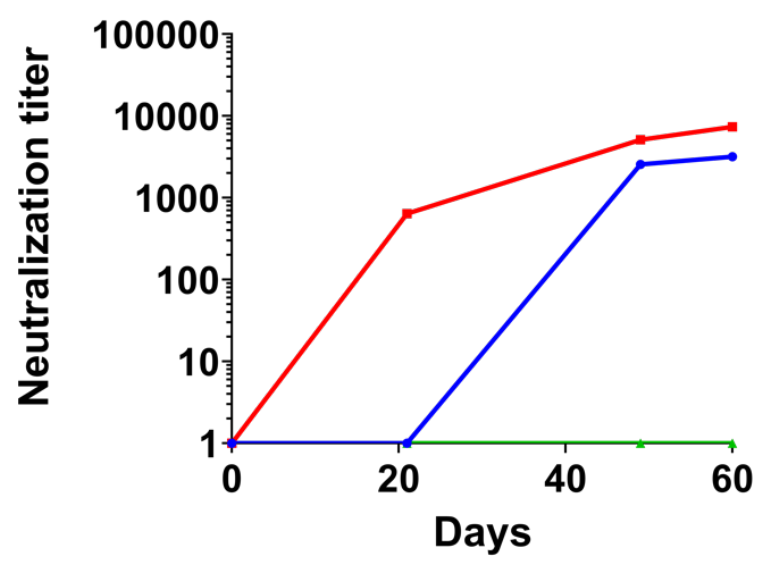

B

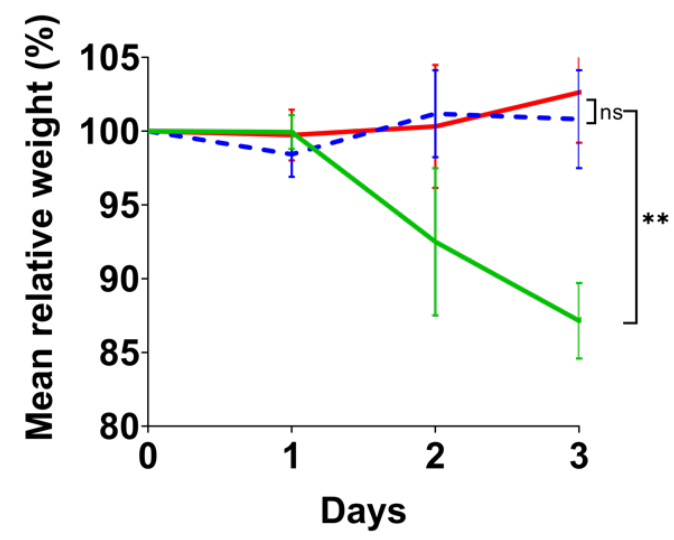

D

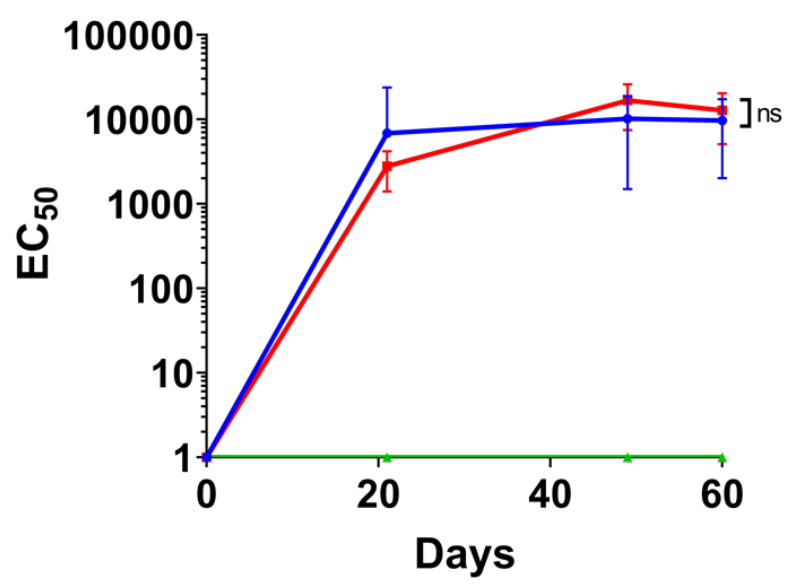

$\mathbf{F}$

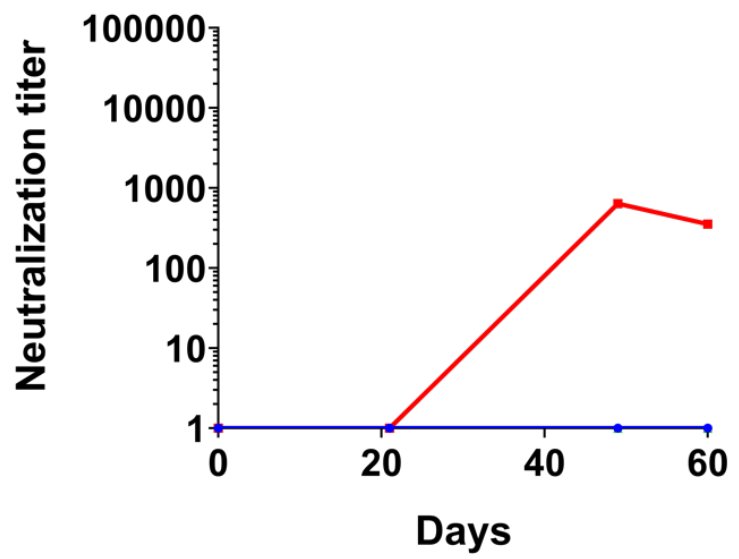

Figure 7. Survival and antibody response of vaccinated mice

Mice were immunized with either MCO-detoxified vaccine (blue), formaldehyde-treated vaccine (red) or an adjuvant control (green) before being challenged with $C$. difficile ( $\mathrm{n}=8$ for all groups). Sera from days $0,21,49$ and 60 were tested for anti-TcdA and anti-TcdB IgG titers by ELISA and neutralizing antibodies by TNA. For ELISA, a four- 
parameter logistic curve was fitted to each serum sample by plotting the absorbance at $450 \mathrm{~nm}$ as a function of the serum dilution. A: Kaplan-Meier survival curve, with day 0 representing the day of $C$. difficile challenge. Statistical analysis of survival curves was performed using Mantel-Cox log-rank test $(p=0.034)$. B: Mean relative weight graph, where the relative weight of each mouse is based on its weight on the day of the challenge. Unpaired Student's t-test was used to compared weight curves. $*=p<0.05, * *=p<0.01,{ }^{* * *}=p<0.001$, ns $=$ no significant difference. C: AntiTcdA IgG titers are shown as $\mathrm{EC}_{50}$ values, representing the serum dilution where the anti-TcdA response is reduced by $50 \%$. Unpaired Student's t-test was used to compare $\mathrm{EC}_{50}$ values at day $60(\mathrm{p}=0.079)$. D: Anti-TcdB IgG titers are shown as $\mathrm{EC}_{50}$ values, representing the serum dilution where the anti-TcdB response is reduced by $50 \%$. Unpaired Student's t-test was used to compare $\mathrm{EC}_{50}$ values at day $60(\mathrm{p}=0.44)$. E: Pooled sera were tested for anti-TcdA neutralization titers, which represents the highest dilution of sera where there is at least $50 \%$ cell survival after $48 \mathrm{~h}$ of adding the toxin-sera mixture. F: Pooled samples were tested for anti-TcdB neutralization titers, which represents the highest dilution of sera where there is at least $50 \%$ cell survival after $48 \mathrm{~h}$ of adding the toxin-sera mixture.

\section{Discussion}

In this study, a mild MCO condition is used as an efficient method to detoxify TcdA and TcdB without altering structural epitopes. MCO detoxification of TcdA and TcdB most likely occurs when metal ions, typically $\mathrm{Cu}^{2+}, \mathrm{Fe}^{2+}$ or $\mathrm{Fe}^{3+}$, interact with exposed functional sites on native TcdA and TcdB. The oxidizing species produced by reaction of copper with $\mathrm{H}_{2} \mathrm{O}_{2}$ remains contentious. However, in our previous studies $[45,46]$ we have shown that $\mathrm{Cu}^{2+}$ and $\mathrm{H}_{2} \mathrm{O}_{2}$ mediate radical production and could lead to alterations in structure and function of the target proteins. The mechanism for the radical production in the presence of $\mathrm{Cu}^{2+}$ and in the absence of any reductant is suggested to be as following: radical anions (reaction 2). Furthermore, the reduced $\mathrm{Cu}^{+}$(cuprous ions) could initiate a Fenton-like reaction with surplus $\mathrm{H}_{2} \mathrm{O}_{2}$ (reaction 3). This reaction could generate $\mathrm{Cu}^{2+}-\mathrm{HO}^{\bullet}$ or its ionized 
513 equivalent, $\mathrm{Cu}^{2+}-\mathrm{O}^{-\bullet}$, as suggested by [54]. Since we have not examined the type of radical produced

514 by the $\mathrm{Cu}^{2+} / \mathrm{H}_{2} \mathrm{O}_{2}$ reaction in this study, it is possible that other active species might be produced and 515 involved in the radical mediated reactions [55]. Hydroxyl radicals and other active species will react 516 almost instantaneously with amino acid side-chains near the interaction site. For this reason, the MCO 517 can be very protein specific depending on specific metal ion interactions sites in the protein as we 518 have seen for TcdA and TcdB in this study.

\subsection{Temperature-induced unfolding of TedA and TcdB}

The temperature study was performed to determine the structural changes in the toxins during increasing temperatures, and thereby determine the highest temperature we could use during the inactivation reaction without altering their structure. The far-UV CD spectroscopy during increasing temperatures show the presence of the characteristic double minima at 208 and $218 \mathrm{~nm}$ for TcdA (Fig. 2A) and $\mathrm{TcdB}$ (Fig. 2B) at $25^{\circ} \mathrm{C}$ and $37^{\circ} \mathrm{C}$, indicating that the toxins possess a well-defined secondary structure. The observed far-UV CD spectra can be explained by the diverse multi-domain structure of the toxins, where each domain has a unique contribution [56,57]. The diverse secondary structure composition is also confirmed from the crystal structures of TcdA [58] and TcdB [59]. The effect of heating on the secondary structure of TcdA and TcdB is very different. Even though both toxins are losing their characteristic and well-defined far-UV CD spectra at temperatures higher than $45^{\circ} \mathrm{C}$, the progression of this change is different. The spectral curve for TcdA displays a progressing 532 decrease in molar ellipticity during heating (Fig. 2A), indicating a shift towards more disordered 533 structure and unfolding of the $\alpha$-helical and $\beta$-sheet structures $[57,60]$. In contrast, the spectral curve 534 for TcdB increases in molar ellipticity and instead progresses into a sharper negative minimum at 216 $535 \mathrm{~nm}$ during heating (Fig. 2B), which could indicate an increase in $\beta$-sheet content [56]. These results 
suggest that thermal denaturation of TcdA and TcdB have different unfolding patterns, in which TcdA unfolds and loses both its $\alpha$-helical and $\beta$-sheet structure, whereas TcdB loses $\alpha$-helical structure and gains a significant amount of new $\beta$-sheet structure. This indicates that TcdB likely aggregates at higher temperatures leading to intermolecular $\beta$-sheet interactions as shown for TcdB in a previous study [57] and also for other proteins [61-63]. Furthermore, the effects of thermal denaturation on

541 TcdA and TcdB is an irreversible process, as cooling the toxins from $50{ }^{\circ} \mathrm{C}$ back to $25{ }^{\circ} \mathrm{C}$ had no 542 effect on restoring their native-like CD spectra, which has also been reported previously by another 543 group [57]. Temperatures between $25^{\circ} \mathrm{C}$ and $37^{\circ} \mathrm{C}$ were concluded to be favorable for detoxification 544 studies, as the toxins were both structurally unmodified until at least $37^{\circ} \mathrm{C}$, while at $45^{\circ} \mathrm{C}$ changes 545 in their secondary structures started to occur.

\subsection{TcdB is more sensitive to acidic $\mathrm{pH}$ changes than TcdA}

The effect of $\mathrm{pH}$ on the thermostability of both toxins were tested by DSF analysis and suggests that the two toxins have quite different $\mathrm{pH}$ sensitivity. TcdA is slightly more heat resistant than TcdB at neutral $\mathrm{pH}$ with a $T_{\mathrm{m}}$ of $51.5^{\circ} \mathrm{C}$ compared to $49{ }^{\circ} \mathrm{C}$ for TcdB. Furthermore, $T_{\mathrm{m}}$ for TcdA in the native folded state is up to $50^{\circ} \mathrm{C}$ in the $\mathrm{pH}$ range between 5 and 7.5 (Fig. 3A), whereas TcdB in the native folded state is up to $47^{\circ} \mathrm{C}$ only between $\mathrm{pH} 6$ and 7.5 (Fig. 3B). These values are consistent with previous studies where Tam et al. [64] found a $T_{\mathrm{m}}$ of $49^{\circ} \mathrm{C}$ for TcdB and Salnikova et al. [57] found $T_{\mathrm{m}}$ values of $52{ }^{\circ} \mathrm{C}$ and $47^{\circ} \mathrm{C}$ for TcdA and TcdB respectively. However, in acidic conditions at $\mathrm{pH} 4.5$, there is a dramatic difference between the folded state of the toxins. TcdA is partially unfolded around $47^{\circ} \mathrm{C}$, and TcdB is partially unfolded at only $32{ }^{\circ} \mathrm{C}$. This is physiologically relevant, as $\mathrm{pH} 4.5$ mimics the environment in the endosomes, and it is known that structural changes occur 
changes we see at $\mathrm{pH} 4.5$ in the DSF analysis is, therefore, a result of the toxins' natural response to 560 acidification, where a structural change occurs to activate translocation across the endosomal 561 membrane [66-68]. TcdB seems to be much more affected by the acidic conditions, as it partially 562 unfolds at a much lower temperature than TcdA. At $\mathrm{pH} 4$, the high initial fluorescence signal and lack 563 of transition phase in the DSF analysis of TcdB, suggests that the toxin is likely unfolded and/or 564 aggregated at lower temperatures [48]. This confirms that acidic conditions ( $\mathrm{pH} 4$ and 4.5) have a 565 significant effect on the unfolding behavior of both toxins, with TcdB being more sensitive to low $566 \mathrm{pH}$ than TcdA.

\subsection{Acidification induced open conformation and $\mathrm{Cu}^{2+}$ catalyzed oxidation of $\mathrm{Tcd} \mathrm{A}$ and $\mathrm{TcdB}$}

It is our hypothesis that partially exposed toxic regions of the TcdA and TcdB would allow maximum accessibility to the produced ROS and thereby inactivation of TcdA and TcdB. Several strategies (see Materials and Methods) to unfold and inactivate were investigated. However, at neutral $\mathrm{pH}$ we did not observe any significant reduction in cytotoxicity albeit loss of protein band intensity on SDS-PAGE was often observed. Thus, we turned our focus on the inherent structural 574 plasticity of the toxins at acidic pH. Our results from the CD (Fig. 2A and 2B) and DSF (Fig. 3A and 3B) in combination with known literature [59,65-68], led us to hypothesize that mimicking the natural environment of the toxins during their cytotoxic mode of action, might facilitate exposure of critical residues necessary for effective oxidative detoxification. Indeed, by lowering the $\mathrm{pH}$ to 4.5 , we could successfully detoxify both TcdA and TcdB using MCO with $\mathrm{Cu}^{2+}$ (Supplementary Fig. S6 and S7). Subsequent control experiments where each component of the MCO reaction, such as $\mathrm{H}_{2} \mathrm{O}_{2}, \mathrm{Cu}^{2+}$ and $\mathrm{pH} 4.5$ were tested separately, confirmed that detoxification only occurred when a combination of the three components was used. Low $\mathrm{pH}$ alone only had a small effect on the 
cytotoxicity of TcdA and TcdB with reductions of around 50-fold and 350-fold respectively

583 (Supplementary Fig. S2 and S3). This is in alignment with our DSF analysis (Fig. 3A and 3B)

584 showing a partial unfolding of the toxins at $\mathrm{pH} 4.5$. However, 50 -fold and 350 -fold reductions in 585 cytotoxicity are insufficient for using the toxoids as safe vaccine antigens, as they are still extremely 586 cytotoxic. The efficacy of our novel approach was only seen when $\mathrm{Cu}^{2+}$ was used in the MCO 587 system, as the usual Fenton catalysts, $\mathrm{Fe}^{2+}$ or $\mathrm{Fe}^{3+}$ in the same system could only reduce the 588 cytotoxicity by 50 -fold and 7-fold respectively (Table 2, Supplementary Fig. S5). These differences 589 are mainly attributed to $\mathrm{Cu}^{2+}$ being a more efficient ROS-generating metal ion compared to $\mathrm{Fe}^{3+}$ and 590 less to the ability of $\mathrm{Cu}^{2+}$ to bind non-specifically to proteins [69-71]. TcdA and TcdB are known to 591 bind metal ions, both having a specific $\mathrm{Zn}^{2+}$ binding site in the autoprotease domain (APD), a 592 requirement for autoprocessing [65]. $\mathrm{Mn}^{2+}$ has also been demonstrated to bind TcdA in the catalytic core of the glucosyltransferase domain (GTD), which consist of a classical Rossman fold [72,73].

594 Similarly, TcdB and the closely related C. sordellii Lethal Toxin (TcsL) have both been shown to 595 have specific binding requirements for $\mathrm{Mn}^{2+}, \mathrm{Co}^{2+}$ and $\mathrm{Mg}^{2+}$, necessary for UDP-glucose hydrolysis 596 and activating their cytotoxic effects [74]. However, in the same study, $\mathrm{Cu}^{2+}$ was shown to be the 597 least effective metal ion for cytotoxic activation of both TcdB and TcsL among a range of tested 598 divalent metal ions. In summary, there are no reports of TcdA and TcdB having specific $\mathrm{Cu}^{2+}$ 599 binding sites, and the likely reason for the $\mathrm{Cu}^{2+}$-specific effects in our MCO system is due to the 600 much higher capacity of $\mathrm{Cu}^{2+} / \mathrm{H}_{2} \mathrm{O}_{2}$ systems to generate $\mathrm{ROS}$ and promote oxidative damage to the 601 toxins.

Finally, we also determined that the molar ratios of 1:60:1000 for TcdA/B: $\mathrm{Cu}^{2+}: \mathrm{H}_{2} \mathrm{O}_{2}$ 603 respectively, were optimal for the MCO components to achieve efficient detoxification of TcdA and $604 \mathrm{TcdB}$. The concentration of $\mathrm{H}_{2} \mathrm{O}_{2}$ in our $\mathrm{MCO}$ system is at least 100 -fold lower than previously 605 reported for detoxification of Pertussis toxin [75] and whole-cell bacteria [76], and around 1000-fold 
606 lower than a hydrogen peroxide-detoxified viral vaccine [77]. Thus, the method described here for 607 detoxification of TcdA and TcdB is orders of magnitude more efficient compared to previously used 608 oxidation methods.

\subsection{Oxidatively induced structural modifications in TcdA and TcdB}

To assess the structural changes induced by MCO in TcdA and TcdB we conducted far-UV CD

612 to study the secondary structure and near-UV CD to study the tertiary structure. These structural 613 studies were complemented with ELISA studies of the epitope integrity with multiple monoclonal 614 antibodies, to evaluate how these structural changes would affect the antibody recognition of various 615 TcdA and TcdB epitopes. According to the far-UV CD spectra, MCO-detoxified TcdA (Fig. 4A) and 616 MCO-detoxified TcdB (Fig. 5A) both have lost the characteristic minimum at $208 \mathrm{~nm}$. This indicates 617 that the MCO detoxification modifies the $\alpha$-helices of TcdA and TcdB. We also see a slight loss in 618 the magnitude of the molar ellipticity over the whole CD spectrum of TcdA, likely caused by 619 increased disordered structure or some degree of precipitation $[57,60]$. TcdB does not show the same 620 trend, instead, we see a more intense negative peak formed around $216 \mathrm{~nm}$, which we also see in the 621 thermal denaturation experiment (Fig. 2B). It should be kept in mind that the MCO-detoxified TcdA and $\mathrm{TcdB}$ are still at $\mathrm{pH} 4.5$, and therefore the $\mathrm{CD}$ spectral changes might also be influenced by structural modifications due to $\mathrm{pH}$ alone. Interestingly, raising the $\mathrm{pH}$ of $\mathrm{MCO}$-detoxified TcdB back to 7.5 , the $\mathrm{CD}$ spectrum reverts and regains a native-like far-UV CD spectrum (Fig. 5A, red line). This suggests that the acidic $\mathrm{pH}$ and not $\mathrm{MCO}$ is the major contributor to the conformational change of the secondary structure of TcdB seen in the far-UV CD (Fig. 5A, blue line). Unfortunately, raising the $\mathrm{pH}$ of TcdA to neutral after MCO detoxification was not suitable for CD analysis, as it led to the loss of overall CD spectrum, likely caused by precipitation. 
To further study whether it is low $\mathrm{pH}$, oxidative damage or the combination of both that is the main contributing factor to the changes in secondary structure seen for TcdA, we followed the 631 progression of the far-UV CD spectrum over time intervals of 3 min. (Supplementary Fig. S9). Two 632 sets of experiments were run, the first with TcdA at $\mathrm{pH} 4.5$ only, and the second with TcdA at $\mathrm{pH} 4.5$ 633 and $\mathrm{MCO}$ components. We found that already in the first spectrum at $0.1 \mathrm{~min}$ there is a slight 634 difference between the MCO spectrum compared to the $\mathrm{pH} 4.5$ only spectrum, with the MCO spectrum showing slightly reduced signal intensity. With further incubation, the MCO spectra show a gradual loss of the characteristic minima at 208 and $218 \mathrm{~nm}$, and overall lower magnitude of molar ellipticity as we also see in Fig. 4A. This progression is plateauing around 15 min after which no 638 further changes were detected even after $2 \mathrm{~h}$. The changes of the TcdA pH 4.5 CD spectrum over 639 time (data not shown) progresses both more slowly and is less extensive compared to the MCO spectrum, suggesting that the oxidative damage caused by MCO contributes to the change in 641 secondary structure. Lastly, we followed the near-UV CD spectrum of MCO-detoxified TcdA over 642 time with measurements made every 3 min during the MCO reaction. It is clear that some structural 643 changes occur in the first $6 \mathrm{~min}$, with a change of both minima at 275 and $282 \mathrm{~nm}$ (Supplementary 644 Fig. S10). The decrease in the near-UV CD spectral intensity in the 275 and $282 \mathrm{~nm}$ region for MCOdetoxified TcdA and TcdB, suggest that tyrosine/tryptophan residues are affected by the MCO (Fig. 4B and 5B). The features in this region, however, remain intact, which indicates that the modifications of the aromatic residue environment are not severe. However, the quality of the near-UV CD spectra makes it difficult to draw any definite conclusions. Nevertheless, from the CD data we can conclude 649 that the majority of structural events caused by MCO are happening within the first 15 min of the 650 reaction, as further incubation only showed insignificant changes in the CD spectra. Interestingly, 651 neither TcdA nor TcdB showed sufficient reduction of cytotoxicity after 15 min of MCO. Even after 30 min of MCO we only saw around a 400-fold reduction in cytotoxicity of TcdA (Supplementary 
653 Fig. S1). To test whether the oxidative damage from 30 min of MCO treatment would continue to 654 cause structural modifications over time even after the MCO reaction was quenched, we stored the 655 sample for $48 \mathrm{~h}$ at $5{ }^{\circ} \mathrm{C}$ and re-tested for cytotoxicity. The level of cytotoxicity was identical to the 656 level seen immediately after the $30 \mathrm{~min} \mathrm{MCO}$, indicating that no further structural modifications 657 happen after the MCO reaction is quenched. A likely explanation could be that after the initial 658 oxidation during the first 15 min, seen on both far-UV and near-UV CD (Supplementary Fig. S9 and 659 S10), there are probably minor secondary events occurring which we cannot visually follow by CD. 660 These secondary events are not causing significant structural changes and therefore are not visible in 661 the CD analysis.

Epitope recognition studies of TcdA and TcdB with monoclonal antibodies show that the MCO 663 treatment is not causing detrimental modifications of the epitopes. The mAb binding to MCO664 detoxified TcdA and TcdB were on average reduced around 2-fold, relative to native TcdA and TcdB. 665 However, when comparing to formaldehyde detoxification, we see a reduction of mAb binding of 666 around 5-fold and 3-fold for TcdA and TcdB, respectively. These results support that our novel MCO 667 system is more epitope conserving to TcdA and TcdB compared to conventional formaldehyde 668 treatment. That oxidation-based detoxification is more epitope conserving than formaldehyde is in 669 line with what was previously shown for Pertussis toxin [38].

\subsection{Toxoids are stable and irreversibly detoxified}

The stability and irreversibility of MCO-detoxified TcdA and TcdB were studied by far-UV

$673 \mathrm{CD}$ analysis and cytotoxicity testing after 4 weeks of storage at either $-20{ }^{\circ} \mathrm{C}, 4{ }^{\circ} \mathrm{C}$ or $25{ }^{\circ} \mathrm{C}$. At all 674 storage conditions, there is a decrease in CD spectral intensity for both native and MCO-detoxified 675 TcdA and TcdB after storage (Fig. 3A-F). This is likely due to protein precipitation during storage, 
as the same is seen for the native toxin samples and therefore cannot be attributed to MCO. The shape of the CD spectra for MCO-detoxified TcdA and TcdB is not changed during the storage at any temperature when compared to its corresponding $\mathrm{CD}$ spectra at day 0 , suggesting that no further structural modifications are happening during long-term storage. Interestingly, it seems that during storage at room temperature $\left(25^{\circ} \mathrm{C}\right)$, the $\mathrm{MCO}$-detoxified samples of both $\mathrm{TcdA}$ and $\mathrm{TcdB}$ are more resistant to precipitation compared to the native toxins (Fig. 3C and 3F). By contrast, we see the same degree of precipitation for the toxins before and after $\mathrm{MCO}$ at $-20{ }^{\circ} \mathrm{C}$ and $4{ }^{\circ} \mathrm{C}$. Importantly, we see no reversion of cytotoxicity after 4 weeks of storage at any temperature, whereas reversion of cytotoxicity is a well-known issue for formaldehyde-detoxified toxins [33,34].

\subsection{Efficacy of oxidatively modified TedA and TcdB vaccine in mice}

Our bivalent vaccine consisting of MCO-detoxified TcdA and TcdB was compared to a similar vaccine consisting of formaldehyde-detoxified toxins, by assessing their ability to protect immunized mice against a lethal $C$. difficile oral challenge and eliciting toxin-specific antibodies. Both vaccines were able to fully protect all mice against the infection (Fig. 7A) as well as concomitant disease symptoms such as diarrhea and weight loss (Fig. 7B). All unvaccinated mice developed disease symptoms and almost $40 \%$ were moribund by day 3 and were euthanized. Hence, the efficacy of the MCO vaccine was sufficient and comparable to the formaldehyde vaccine in protecting all mice from disease symptoms. Induction of serum IgG against native TcdA and TcdB was measured by ELISA (Fig. 7C and 7D) with no statistically significant differences between the mean IgG responses elicited by the MCO-detoxified or formaldehyde-detoxified vaccine, suggesting that the two methods are comparable with regards to immunogenicity. However, mice immunized with the MCO-detoxified vaccine had lower serum levels of toxin-neutralizing antibodies compared to the group receiving the 
699

700

formaldehyde-detoxified vaccine. The mean anti-TcdA neutralizing antibody titer in the MCO vaccine group was only around half of the formaldehyde vaccine group (Fig. 7E) and we failed to detect anti-TcdB neutralizing antibodies in the MCO vaccine group, while low levels of neutralizing activity against TcdB was detected in the sera from the formaldehyde vaccine group (Fig. 7F). The results suggest that the MCO-detoxified vaccine is slightly less efficient in eliciting neutralizing antibodies against TcdA and TcdB compared to the formaldehyde-detoxified vaccine.

Neutralizing antibodies are crucial in CDI prevention, as they recognize and bind key epitopes on the toxins that prevent them from entering the host cells and causing disease symptoms [78-81]. Our epitope recognition studies showed significantly higher binding of various mAbs to the MCOdetoxified toxins compared to formaldehyde-detoxified ones, indicating that the epitopes were closer to the native state (Table 3 and 4). This is supported by previous studies showing that oxidation-based detoxification of toxins, bacteria and viruses are significantly more epitope-conserving than formaldehyde $[38,76,77]$. We, therefore, believe that this issue is caused by some other factor(s) than direct modifications of key epitopes by $\mathrm{MCO}$, and further optimization of our MCO-detoxification method is likely needed. Neutralizing antibodies against TcdB have been shown in several hamster studies to develop much more slowly than for TcdA, and require up to four immunizations over three months to reach the same levels $[20,21,82]$. The difficulty of stimulating anti-TcdB neutralizing antibodies, in general, might have contributed to the lower levels of neutralizing TcdB antibodies we detected, which were also very low in the formaldehyde vaccine group.

In conclusion, using mild $\mathrm{Cu}^{2+} / \mathrm{H}_{2} \mathrm{O}_{2}$-catalyzed oxidation in combination with $\mathrm{pH}$-dependent structural modulation we demonstrate efficient detoxification of TcdA and TcdB. The detoxification resulted in a significant reduction in toxicity yet maintaining the toxoids of TcdA and TcdB structurally preserved. Furthermore, our method resulted in the development of immunogenic toxoids highly recognizable by an array of monoclonal antibodies against TcdA and TcdB and capable of 
723 protecting mice against CDI. Thus, the method may very well be suitable for the creation of safe 724 toxoid-based antigens and a potential replacement for formaldehyde detoxification in future vaccine 725 development. 


\section{Author Contributions}

727 AA designed, executed, supervised and participated in all experiments, collected and analyzed all 728 data, performed toxin purification, CD, DSF, MCO and epitope recognition experiments (Figs. 1 - 7 729 and Tables 1 - 4), made all the figures and tables and wrote the manuscript. MKT designed, executed 730 and supervised the MCO experiments (Table 2) and CD studies (Fig. 4 and 5), participated in making 731 Fig. 1, revised and contributed intellectually to the manuscript. SSMM designed, performed and 732 collected data for the stability experiments (Fig. 6). SJN designed the animal study and performed 733 serum ELISA and TNA studies and collected data for Fig. 7. ABH contributed to the development of 734 the methods used in the production and purification of TcdA and TcdB. IMM contributed with 735 helpful intellectual suggestions at a number of meetings and by reading and editing the manuscript. 736 KAK contributed by helping with ELISA studies and in vivo experiments and has revised and 737 contributed to the manuscript with intellectual content and final revision. MJB conceived the idea of 738 using copper ions for the metal-catalyzed oxidation and designed, supervised and funded the MCO 739 and CD experiments, revised and contributed to the manuscript with intellectual content. RJ 740 conceived the idea for oxidation-based detoxification of $\mathrm{TcdA}$ and $\mathrm{TcdB}$, funded and administered 741 the study, designed and supervised all experiments, revised and contributed intellectually to the 742 manuscript. All authors have read and approved the final version to be published.

\section{Acknowledgments}

745 We would like to thank Susanne Jespersen at Statens Serum Institut for invaluable help with the 746 endless culturing of Vero cells during the entire study. We gratefully acknowledge financial support 747 from the Novo Nordisk Foundation (Grant no.: NNF17OC0029548 to RJ), the Danish Council for 
748 Independent Research Technology and Production Sciences (Grant no.: DFF| FTP 4005-00082) and 749 the Lundbeck Foundation postdoctoral fellowship (Grant no.: R231-2016-3276 to MKT).

750

751 Declarations of interest

752 We declare no conflict of interest 


\section{References}

[1] F. Lessa, Y. Mu, W. Bamberg, Z. Beldavs, G. Dumyati, J. Dunn, M. Farley, S. Holzbauer, J. Meek, E. Phipps, L. Wilson, L. Winston, J. Cohen, B. Limbago, S. Fridkin, D. Gerding, L. McDonald, Burden of Clostridium difficile Infection in the United States, N. Engl. J. Med. 372 (2015) 825-834.

[2] E. Balsells, T. Shi, C. Leese, I. Lyell, J. Burrows, C. Wiuff, H. Campbell, M.H. Kyaw, H. Nair, Global burden of Clostridium difficile infections: A systematic review and metaanalysis, J. Glob. Health. 9 (2019).

[3] S. Khanna, D.S. Pardi, S.L. Aronson, P. Patricia, R. Orenstein, J.L.S. Sauver, W.S. Harmsen, A.R. Zinsmeister, The Epidemiology of Community-acquired Clostridium difficile infection: A population-based study, Am. J. Gastroenterol. 107 (2012) 89-95.

[4] M. Rupnik, M.H. Wilcox, D.N. Gerding, Clostridium difficile infection: new developments in epidemiology and pathogenesis, Nat. Publ. Gr. 7 (2009) 526-536.

[5] D. Wu, A. Joyee, S. Nandagopal, M. Lopez, X. Ma, J. Berry, F. Lin, Effects of Clostridium difficile Toxin A and B on Human T Lymphocyte Migration, Toxins (Basel). 5 (2013) 926938.

[6] R.N. Pruitt, B. Chagot, M. Cover, W.J. Chazin, B. Spiller, D.B. Lacy, Structure-Function Analysis of Inositol Hexakisphosphate-induced Autoprocessing in Clostridium difficile Toxin A, J. Biol. Chem. 284 (2009) 21934-21940.

[7] D.E. Voth, J.D. Ballard, Clostridium difficile Toxins: Mechanism of Action and Role in Disease, Clin. Microbiol. Rev. 18 (2005) 247-263.

[8] D.M. Lyerly, K.E. Saum, D.K. Macdonald, T.D. Wilkins, Effects of Clostridium difficile Toxins Given Intragastrically to Animals, Infect. Immun. 47 (1985) 349-352.

[9] C. Fiorentini, A. Fabbri, L. Falzano, A. Fattorossi, P. Matarrese, R. Rivabene, G. Donelli, 
Clostridium difficile Toxin B Induces Apoptosis in Intestinal Cultured Cells, Infect. Immun. 66 (1998) 2660-2665.

[10] M. Riegler, R. Sedivy, C. Pothoulakis, G. Hamilton, J. Zacherl, G. Bischof, E. Cosentini, W. Feil, R. Schiessel, J.T. Lamont, E. Wenzl, Clostridium difficile Toxin B Is More Potent than Toxin A in Damaging Human Colonic Epithelium In Vitro, J. Clin. Invest. 95 (2011) 20042011.

[11] G.P. Carter, J.I. Rood, D. Lyras, The role of toxin A and toxin B in Clostridium difficileassociated disease: Past and present perspectives., Gut Microbes. 1 (2010) 58-64.

[12] S.A. Kuehne, S.T. Cartman, J.T. Heap, M.L. Kelly, A. Cockayne, N.P. Minton, The role of toxin A and toxin B in Clostridium difficile infection, Nature. 467 (2010) 711-713.

[13] Z. Peng, L. Ling, C.W. Stratton, C. Li, C.R. Polage, B. Wu, Y.W. Tang, Advances in the diagnosis and treatment of Clostridium difficile infections review-article, Emerg. Microbes Infect. 7 (2018).

[14] Z. Peng, D. Jin, H.B. Kim, C.W. Stratton, B. Wu, Y.-W. Tang, X. Sun, Update on Antimicrobial Resistance in Clostridium difficile: Resistance Mechanisms and Antimicrobial Susceptibility Testing, J. Clin. Microbiol. 55 (2017) 1998-2008.

[15] P. Spigaglia, Recent advances in the understanding of antibiotic resistance in Clostridium difficile infection, Ther. Adv. Infect. Dis. 3 (2016) 23-42.

[16] S. Johnson, Recurrent Clostridium difficile infection: A review of risk factors, treatments, and outcomes, J. Infect. 58 (2009) 403-410.

[17] J. Freeman, S.D. Baines, K. Saxton, M.H. Wilcox, Effect of metronidazole on growth and toxin production by epidemic Clostridium difficile PCR ribotypes 001 and 027 in a human gut model, J. Antimicrob. Chemother. 60 (2007) 83-91.

[18] E. van Nood, P. Speelman, E.J. Kuijper, J.J. Keller, Struggling with recurrent Clostridium 
difficile infections: is donor faeces the solution?, Eurosurveillance. 14 (2009).

803

804

805

806

807

808

809

810

[19] E. Gough, H. Shaikh, A.R. Manges, Systematic Review of Intestinal Microbiota Transplantation (Fecal Bacteriotherapy) for Recurrent Clostridium difficile Infection, Clin. Infect. Dis. 53 (2011) 994-1002.

[20] R.G.K. Donald, M. Flint, N. Kalyan, E. Johnson, S.E. Witko, C. Kotash, P. Zhao, S. Megati, I. Yurgelonis, P.K. Lee, Y. V Matsuka, E. Severina, A. Deatly, M. Sidhu, K.U. Jansen, N.P. Minton, A.S. Anderson, A novel approach to generate a recombinant toxoid vaccine against Clostridium difficile., Microbiology. 159 (2013) 1254-66.

[21] N.G. Anosova, A.M. Brown, L. Li, N. Liu, L.E. Cole, J. Zhang, H. Mehta, H. Kleanthous, Systemic antibody responses induced by a two-component Clostridium difficile toxoid vaccine protect against C. difficile-associated disease in hamsters, J. Med. Microbiol. 62 (2013) 1394-1404.

[22] G. Foglia, S. Shah, C. Luxemburger, P.J. Freda, Clostridium difficile: Development of a novel candidate vaccine, Vaccine. 30 (2012) 4307-4309.

[23] S. Sougioultzis, L. Kyne, D. Drudy, S. Keates, S. Maroo, C. Pothoulakis, P.J. Giannasca, C.K. Lee, M. Warny, T.P. Monath, C.P. Kelly, Clostridium difficile toxoid vaccine in recurrent C. difficile-associated diarrhea, Gastroenterology. 128 (2005) 764-770.

[24] H. Qiu, R. Cassan, D. Johnstone, X. Han, A.G. Joyee, M. McQuoid, A. Masi, J. Merluza, B. Hrehorak, R. Reid, K. Kennedy, B. Tighe, C. Rak, M. Leonhardt, B. Dupas, L. Saward, J.D. Berry, C.L. Nykiforuk, Novel clostridium difficile anti- Toxin (TcdA and TcdB) humanized monoclonal antibodies demonstrate in vitro neutralization across a broad spectrum of clinical strains and in vivo potency in a hamster spore challenge model, PLoS One. 11 (2016) 1-21.

[25] A.J. Marozsan, D. Ma, K.A. Nagashima, B.J. Kennedy, Y.K. Kang, R.R. Arrigale, G.P. Donovan, W.W. Magargal, P.J. Maddon, W.C. Olson, Protection against clostridium difficile 
infection with broadly neutralizing antitoxin monoclonal antibodies, J. Infect. Dis. 206 (2012) 706-713.

[26] ClinicalTrials.gov Identifier: NCT02316470, (n.d.).

829 [27] ClinicalTrials.gov Identifier: NCT03918629, (n.d.).

830 [28] ClinicalTrials.gov Identifier: NCT01887912, (n.d.).

831 [29] T.-A. Morten, B.J. Sys, S.W. Ellen, W.P. Jesper, H. Peter, Investigation of the detoxification mechanism of formaldehyde-treated tetanus toxin, Vaccine. 25 (2007) 2213-2227.

[30] C. Neumüller, Detoxification of Diphtheria Toxin with Formaldehyde mixed with an AminoAcid, Nature. 174 (1954) 405-406.

[32] FDA, Vaccines Licensed for Use in the United States, 2019. (n.d.).

[34] E. Vidunas, A. Mathews, M. Weaver, P. Cai, E.H. Koh, S. Patel-Brown, H. Yuan, Z. rong Zheng, M. Carriere, J.E. Johnson, J. Lotvin, J. Moran, Production and Characterization of Chemically Inactivated Genetically Engineered Clostridium difficile Toxoids, J. Pharm. Sci. 105 (2016) 2032-2041.

[35] R.C. Grafstrom, A.J. Fornace, H. Autrup, J.F. Lechner, C.C. Harris, Formaldehyde damage to DNA and inhibition of DNA repair in human bronchial cells, Science (80-. ). 220 (1983) $216-218$. 
[36] M. Soffritti, C. Maltoni, F. Maffei, R. Biagi, Formaldehyde: An experimental multipotential carcinogen, Toxicol. Ind. Health. 5 (1989) 699-730.

[37] R.G.A. Jones, Y. Liu, P. Rigsby, D. Sesardic, An improved method for development of toxoid vaccines and antitoxins, J. Immunol. Methods. 337 (2008) 42-48. https://doi.org/10.1016/j.jim.2008.05.009.

[38] P.H. Ibsen, The effect of formaldehyde, hydrogen peroxide and genetic detoxification of pertussis toxin on epitope recognition by murine monoclonal antibodies, Vaccine. 14 (1996) $359-368$.

[39] A. Di Tommaso, M.T. De Magistris, M. Bugnoli, I. Marsili, R. Rappuoli, S. Abrignani, Formaldehyde treatment of proteins can constrain presentation to $\mathrm{T}$ cells by limiting antigen processing, Infect. Immun. 62 (1994) 1830-1834.

[40] L. Chen, M. Tang, C. Chen, M. Chen, K. Luo, J. Xu, D. Zhou, F. Wu, Efficient Bacterial Inactivation by Transition Metal Catalyzed Auto-Oxidation of Sulfite, Environ. Sci. Technol. $51(2017) 12663-12671$.

[41] R.A. Clark, Oxidative inactivation of pneumolysin by the myeloperoxidase system and stimulated human neutrophils, J. Immunol. 136 (1986) 4617-4622.

[42] A. Jekle, J. Yoon, M. Zuck, R. Najafi, L. Wang, T. Shiau, C. Francavilla, S.A. Rani, C. Eitzinger, M. Nagl, M. Anderson, D. Debabov, NVC-422 inactivates staphylococcus aureus toxins, Antimicrob. Agents Chemother. 57 (2013) 924-929.

[43] G.R. Siber, N. Thakrar, B.A. Yancey, L. Herzog, C. Todd, N. Cohen, R.D. Sekura, C.U. Lowe, Safety and immunogenicity of hydrogen peroxide-inactivated pertussis toxoid in 18month-old children, Vaccine. 9 (1991) 735-740.

[44] I. Krantz, R. Sekura, B. Trollfors, J. Taranger, G. Zackrisson, T. Lagergard, R. Schneerson, J. Robbins, Immunogenicity and safety of a pertussis vaccine composed of pertussis toxin 
inactivated by hydrogen peroxide, in 18- to 23-month-old children, J. Pediatr. 116 (1990) $539-543$.

[45] M.K. Tiwari, F. Leinisch, C. Sahin, I.M. Møller, D.E. Otzen, M.J. Davies, M.J. Bjerrum, Early events in copper-ion catalyzed oxidation of $\alpha$-synuclein, Free Radic. Biol. Med. 121 (2018) 38-50.

[46] M.K. Tiwari, P.M. Hägglund, I.M. Møller, M.J. Davies, M.J. Bjerrum, Copper ion / H2O2 oxidation of $\mathrm{Cu} / \mathrm{Zn}$-Superoxide dismutase: Implications for enzymatic activity and antioxidant action, Redox Biol. 26 (2019) 101262.

[47] L. Wentzel, M. Sterne, A. Polson, High toxicity of pure botulinum type D toxin, Nature. 166 (1950) 739-740.

[48] S. Boivin, S. Kozak, R. Meijers, Optimization of protein purification and characterization using Thermofluor screens, Protein Expr. Purif. 91 (2013) 192-206.

[49] Ammerman, Vero cell line maintenance, Curr Protoc Microbiol. (2009) 1-10.

[50] X. Chen, K. Katchar, J.D. Goldsmith, N. Nanthakumar, A. Cheknis, D.N. Gerding, C.P. Kelly, A Mouse Model of Clostridium difficile-Associated Disease, Gastroenterology. 135 (2008) 1984-1992.

[51] L.T. Erikstrup, M. Aarup, R. Hagemann-Madsen, F. Dagnaes-Hansen, B. Kristensen, K.E.P. Olsen, K. Fuursted, Treatment of Clostridium difficile infection in mice with vancomycin alone is as effective as treatment with vancomycin and metronidazole in combination, BMJ Open Gastroenterol. 2 (2015) 1-9.

[52] H. Krivan, T. Wilkins, Purification of Clostridium difficile Toxin A by Affinity, Infect. Immun. 55 (1987) 1873-1877.

[53] S.W. Fu, J. Xue, Y.L. Zhang, D.Y. Zhou, Simplified purification method for Clostridium difficile toxin A, World J. Gastroenterol. 10 (2004) 2756-2758. 
[54] T. Ookawara, N. Kawamura, Y. Kitagawa, N. Taniguchi, Site-specific and random fragmentation of $\mathrm{Cu}, \mathrm{Zn}$-superoxide dismutase by glycation reaction. Implication of reactive oxygen species, J. Biol. Chem. 267 (1992) 18505-18510.

[55] S. Goldstein, D. Meyerstein, Commentary: Comments on the mechanism of the "Fentonlike" reaction, Acc. Chem. Res. 32 (1999) 547-550.

[56] D. Corrêa, C. Ramos, The use of circular dichroism spectroscopy to study protein folding, form and function, African J Biochem Res. 3 (2009) 164-173.

[57] M.S. Salnikova, S.B. Joshi, J.H. Rytting, M. Warny, C.R. Middaugh, Physical characterization of clostridium difficile toxins and toxoids: Effect of the formaldehyde crosslinking on thermal stability, J. Pharm. Sci. 97 (2008) 3735-3752.

[58] N.M. Chumbler, S.A. Rutherford, Z. Zhang, M.A. Farrow, J.P. Lisher, E. Farquhar, D.P. Giedroc, B.W. Spiller, R.A. Melnyk, D.B. Lacy, Crystal structure of Clostridium difficile toxin A, Nat. Microbiol. 1 (2016) 1-15.

[59] P. Chen, K. Lam, Z. Liu, F.A. Mindlin, B. Chen, C.B. Gutierrez, L. Huang, Y. Zhang, T. Hamza, H. Feng, T. Matsui, M.E. Bowen, K. Perry, R. Jin, Structure of the full-length Clostridium difficile toxin B, Nat. Struct. Mol. Biol. 26 (2019) 712-719.

[60] K. Matsuo, Y. Sakurada, R. Yonehara, M. Kataoka, K. Gekko, Secondary-structure analysis of denatured proteins by vacuum-ultraviolet circular dichroism spectroscopy, Biophys. J. 92 (2007) 4088-4096.

[61] B. Shivu, S. Seshadri, J. Li, K.A. Oberg, V.N. Uversky, A.L. Fink, Distinct $\beta$-sheet structure in protein aggregates determined by ATR-FTIR spectroscopy, Biochemistry. 52 (2013) $5176-5183$.

[62] O. Gursky, S. Aleshkov, Temperature-dependent $\beta$-sheet formation in $\beta$-amyloid A $\beta 1-40$ peptide in water: Uncoupling $\beta$-structure folding from aggregation, Biochim. Biophys. Acta - 
Protein Struct. Mol. Enzymol. 1476 (2000) 93-102.

[63] F. Ding, J.J. LaRocque, N. V. Dokholyan, Direct observation of protein folding, aggregation, and a prion-like conformational conversion, J. Biol. Chem. 280 (2005) 40235-40240.

[64] J. Tam, G.L. Beilhartz, A. Auger, P. Gupta, A.G. Therien, R.A. Melnyk, Small Molecule Inhibitors of Clostridium difficile Toxin B-Induced Cellular Damage, Chem. Biol. 22 (2015) $175-185$.

[65] R.N. Pruitt, M.G. Chambers, K.K.-S. Ng, M.D. Ohi, D.B. Lacy, Structural organization of the functional domains of Clostridium difficile toxins A and B, Proc. Natl. Acad. Sci. 107 (2010) 13467-13472.

[66] M. Qa'dan, L.M. Spyres, J.D. Ballard, pH-induced conformational changes in Clostridium difficile toxin B, Infect. Immun. 68 (2000) 2470-2474.

[67] T. Giesemann, T. Jank, R. Gerhard, E. Maier, I. Just, R. Benz, K. Aktories, Cholesteroldependent pore formation of Clostridium difficile toxin A, J. Biol. Chem. 281 (2006) 1080810815.

[68] H. Barth, G. Pfeifer, F. Hofmann, E. Maier, R. Benz, K. Aktories, Low ph-induced Formation of Ion Channels by Clostridium difficile Toxin B in Target Cells, J. Biol. Chem. 276 (2001) 10670-10676.

[69] L. Pecci, G. Montefoschi, D. Cavallini, Some new details of the copper-hydrogen peroxide interaction, Biochem. Biophys. Res. Commun. 235 (1997) 264-267.

[70] M.E. Letelier, S. Sánchez-Jofré, L. Peredo-Silva, J. Cortés-Troncoso, P. Aracena-Parks, Mechanisms underlying iron and copper ions toxicity in biological systems: Pro-oxidant activity and protein-binding effects, Chem. Biol. Interact. 188 (2010) 220-227.

[71] O.I. Aruoma, B. Halliwell, E. Gajewski, M. Dizdaroglu, Copper-ion-dependent damage to the bases in DNA in the presence of hydrogen peroxide, Biochem. J. 273 (1991) 601-604. 
https://doi.org/10.1042/bj2730601.

[72] R.N. Pruitt, N.M. Chumbler, S.A. Rutherford, M.A. Farrow, D.B. Friedman, B. Spiller, D.B.

[78] G.J. Babcock, T.J. Broering, H.J. Hernandez, R.B. Mandell, K. Donahue, N. Boatright, A.M. Stack, I. Lowy, R. Graziano, D. Molrine, D.M. Ambrosino, W.D. Thomas, I.N.I. Mmun, Human Monoclonal Antibodies Directed against Toxins A and B Prevent Clostridium difficile-Induced Mortality in Hamsters, Infect. Immun. 74 (2006) 6339-6347.

[79] G. Corthier, M.C. Muller, T.D. Wilkins, D. Lyerly, R. L’Hardion, Protection against experimental pseudomembranous colitis in gnotobiotic mice by use of monoclonal antibodies against Clostridium difficile toxin A, Infect. Immun. 59 (1991) 1192-1195. 
970 [80] J.F. Torres, D.M. Lyerly, J.E. Hill, T.P. Monath, Evaluation of formalin-inactivated Clostridium difficile vaccines administered by parenteral and mucosal routes of immunization in hamsters, Infect. Immun. 63 (1995) 4619-4627.

973 [81] I. Lowy, D.C. Molrine, B.A. Leav, B.M. Blair, R. Baxter, D.N. Gerding, G. Nichol, W.D. Thomas, M. Leney, S. Sloan, C.A. Hay, D.M. Ambrosino, Treatment with monoclonal

[82] S. Secore, S. Wang, J. Doughtry, J. Xie, M. Miezeiewski, R.R. Rustandi, M. Horton, R. Xoconostle, B. Wang, C. Lancaster, A. Kristopeit, S.C. Wang, S. Christanti, S. Vitelli, M.P. Gentile, A. Goerke, J. Skinner, E. Strable, D.S. Thiriot, J.L. Bodmer, J.H. Heinrichs, Development of a novel vaccine containing binary toxin for the prevention of Clostridium difficile disease with enhanced efficacy against NAP1 strains, PLoS One. 12 (2017) 1-23. 


\section{Detoxification of Toxin A and Toxin B by copper ion-catalyzed 985 oxidation in production of a toxoid-based vaccine against Clostridioides 986 difficile}

988 Aria Aminzadeh ${ }^{1,2, \S}$, Manish K. Tiwari ${ }^{2, \S}$, Srwa Satar Mamah Mustapha ${ }^{1}$, Sandra Junquera 989 Navarrete $^{1}$, Anna Bielecka Henriksen ${ }^{1}$, Ian Max Møller ${ }^{3}$, Karen Angeliki Krogfelt ${ }^{4}$, Morten Jannik 990 Bjerrum², René Jørgensen ${ }^{1, *}$

$992{ }^{1}$ Statens Serum Institut, Department of Bacteria, Parasites and Fungi, Copenhagen, Denmark

993 2University of Copenhagen, Department of Chemistry, Copenhagen, Denmark

$994{ }^{3}$ Department of Molecular Biology and Genetics, Aarhus University, Forsøgsvej 1, DK-4200 995 Slagelse, Denmark

$996 \quad{ }^{4}$ Roskilde University, Molecular and Medical Biology, Roskilde Denmark 997

$998 *$ Correspondence to: renj@ssi.dk

999 René Jørgensen

1000 Statens Serum Institut, Department of Bacteria, Parasites and Fungi,

1001 Artillerivej 5, 2300 Copenhagen S, Denmark 


\section{Contents}

1004 Fig. S1. In vitro cytotoxicity on Vero cells of TcdA detoxified by MCO using with varying incubation 1005 times.

1006 Fig. S2. In vitro cytotoxicity on Vero cells of MCO control samples with TcdA.

1007 Fig. S3. In vitro cytotoxicity on Vero cells of MCO control samples with TcdB.

1008 Fig. S4. C. difficile toxin yield in various growth media tested on Vero cells.

1009 Fig. S5. In vitro cytotoxicity on Vero cells of TcdA detoxified by MCO using with different metal 1010 ions.

1011 Fig. S6. In vitro cytotoxicity on Vero cells of native and MCO-detoxified TcdA.

1012 Fig. S7. In vitro cytotoxicity on Vero cells of native and MCO-detoxified TcdB.

1013 Fig. S8. In vitro cytotoxicity on Vero cells of TcdA detoxified by MCO at varying temperatures.

1014 Fig. S9. Far-UV circular dichroism analysis of the structural effect of MCO detoxification on TcdA.

1015 Fig. S10. Near-UV circular dichroism analysis of the structural effect of MCO detoxification on 1016 TcdA.

1017 Table S1. Molar ratios and experimental conditions used for the MCO pilot study of TcdA. 1018 1019 1020 


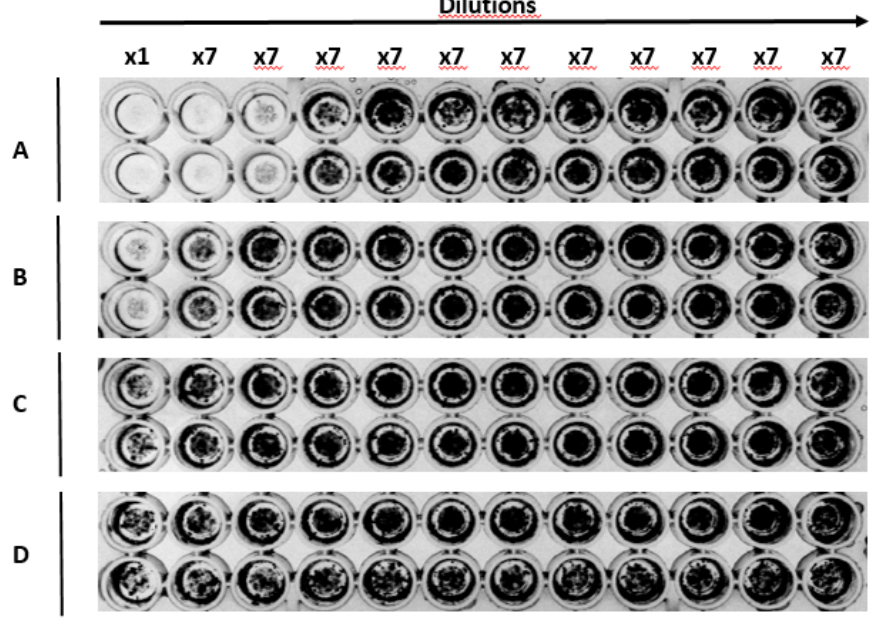

1022

1023

1024

1025

1026

1027

Fig. S1. In vitro cytotoxicity on Vero cells of TedA detoxified by MCO using different incubation times. Microtiter plates were stained with crystal violet after $48 \mathrm{~h}$ incubation and photographed to visualize cell survival (black wells). All samples were tested as duplicates and consisted of $2 \mu \mathrm{g}$ MCO-detoxified TcdA added to the first column and serially diluted horizontally. All samples were incubated at $37^{\circ} \mathrm{C}$. A) $30 \mathrm{~min} \mathrm{B)} 60 \mathrm{~min}$ C) $90 \mathrm{~min}$ D) $120 \mathrm{~min}$.
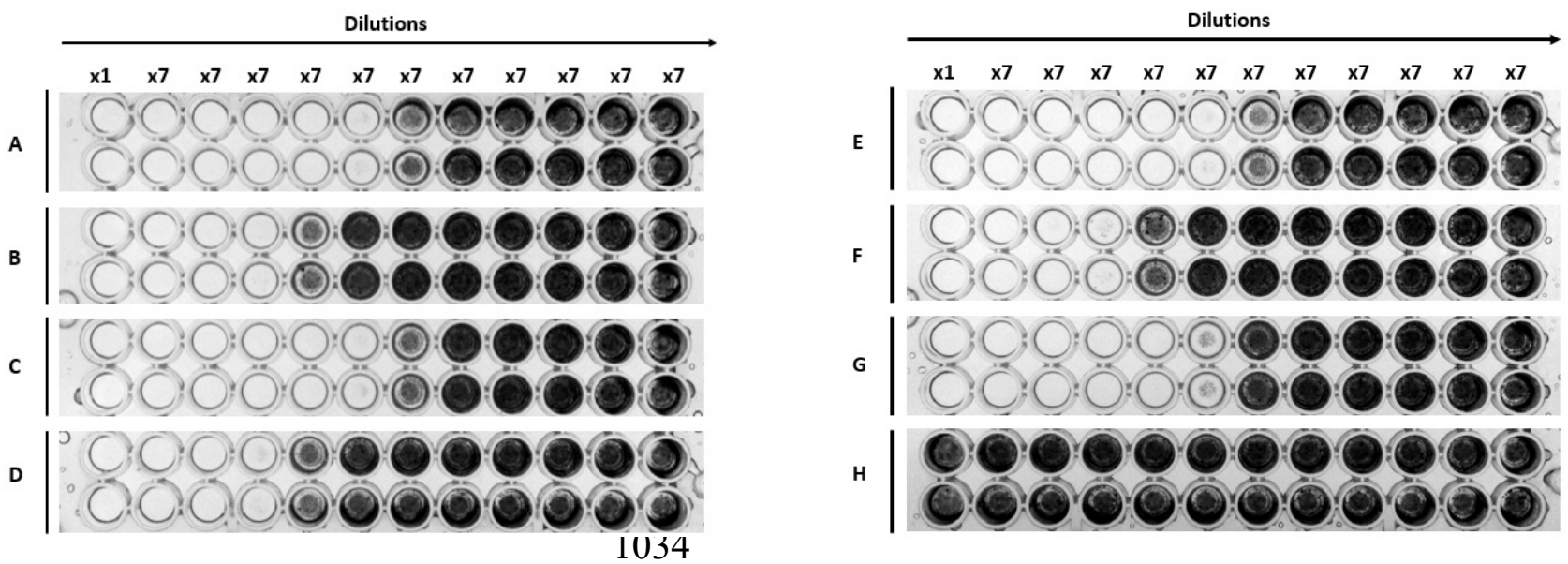

Fig. S2. In vitro cytotoxicity on Vero cells of MCO control samples with TcdA. Plates were stained as described in Fig S1. All samples were tested as duplicates and consisted of $1.9 \mu \mathrm{g} \mathrm{TcdA}$ added to first column and serially diluted horizontally. All samples were incubated for $2 \mathrm{~h}$ at $37^{\circ} \mathrm{C}$. A) Native TcdA in pH 7.5 B) Native TcdA in pH 4.5 C) TcdA $+\mathrm{H}_{2} \mathrm{O}_{2}$ in pH 7.5 D) TcdA $+\mathrm{H}_{2} \mathrm{O}_{2}$ in pH 4.5 E) $\mathrm{TcdA}+\mathrm{CuCl}_{2}$ in pH 7.5 F) $\mathrm{TcdA}+\mathrm{CuCl}_{2}$ in pH 4.5 G) $\mathrm{TcdA}+\mathrm{H}_{2} \mathrm{O}_{2}+$ $\mathrm{CuCl}_{2}$ in $\mathrm{pH} 7.5$ (MCO) $\left.\mathrm{H}\right) \mathrm{TcdA}+\mathrm{H}_{2} \mathrm{O}_{2}+\mathrm{CuCl}_{2}$ in $\mathrm{pH} 4.5$ (MCO). 
Dilutions

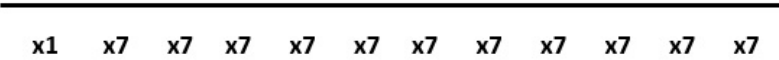

A

в

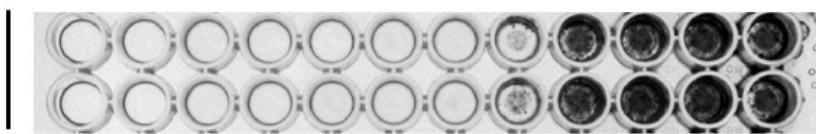

c

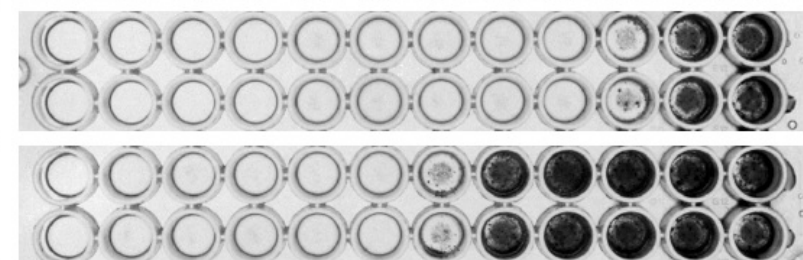

Dilution

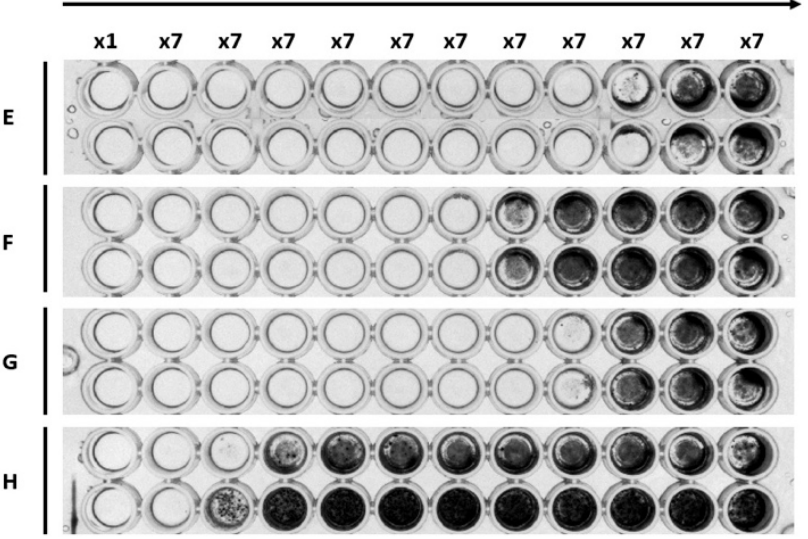

1040

1041

1042

1043

1044

1045

1046

1047

1048

Fig. S3. In vitro cytotoxicity on Vero cells of MCO control samples with TedB. Plates were stained with crystal violet after $48 \mathrm{~h}$ incubation and photographed to visualize cell survival in each well with black stain. All samples were tested as duplicates and consisted of $1.75 \mu \mathrm{g}$ TcdB added to first column and serially diluted horizontally. All samples were incubated for $2 \mathrm{~h}$ at $37^{\circ} \mathrm{C}$. A) Native TcdB in $\left.\mathrm{pH} 7.5 \mathrm{~B}\right)$ Native TcdB in pH 4.5 C) $\mathrm{TcdB}+\mathrm{H}_{2} \mathrm{O}_{2}$ in $\mathrm{pH} 7.5 \mathrm{D}$ ) $\mathrm{TcdB}+\mathrm{H}_{2} \mathrm{O}_{2}$ in $\left.\mathrm{pH} 4.5 \mathbf{E}\right) \mathrm{TcdB}+\mathrm{CuCl}_{2}$ in $\mathrm{pH} 7.5$ F) $\mathrm{TcdB}+\mathrm{CuCl}_{2}$ in $\mathrm{pH} 4.5$ G) $\mathrm{TcdB}+\mathrm{H}_{2} \mathrm{O}_{2}+\mathrm{CuCl}_{2}$ in $\mathrm{pH} 7.5$ (MCO) $\mathrm{H}) \mathrm{TcdB}+\mathrm{H}_{2} \mathrm{O}_{2}+\mathrm{CuCl}_{2}$ in $\mathrm{pH} 4.5(\mathrm{MCO})$.

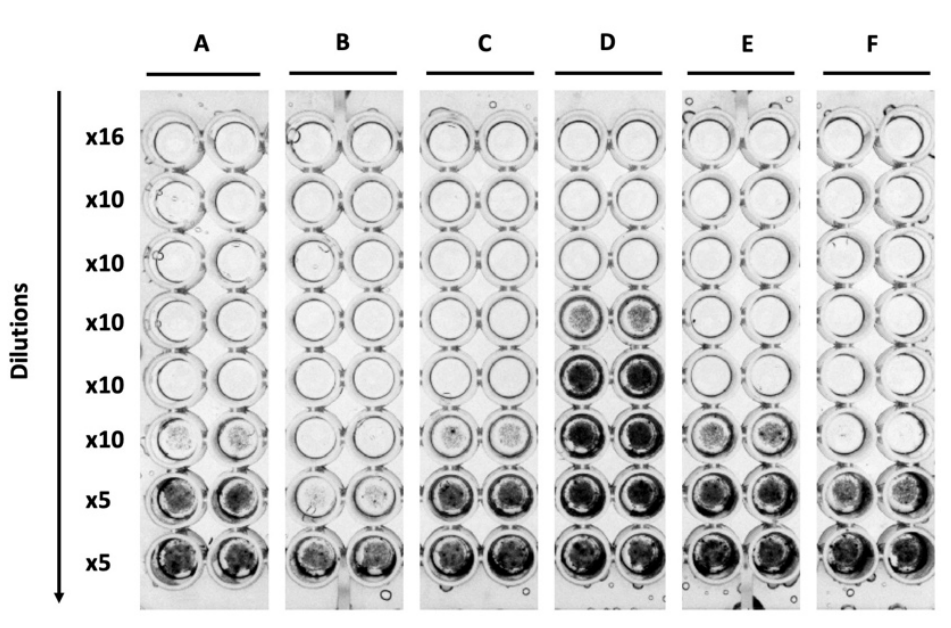

Fig. S4. $C$. difficile toxin yield in various growth media tested on Vero cells. Samples were taken from each culture after 48 hours of growth, centrifuged and filtered. Ten $\mu \mathrm{L}$ was added to the first row (x16) and serially diluted vertically. Plates were stained with crystal violet after $48 \mathrm{~h}$ incubation and photographed to visualize cell survival in each well with black stain. All samples were tested as duplicates and consisted of $20 \mathrm{~g} / \mathrm{L}$ yeast extract, $1 \mathrm{~g} / \mathrm{L}$ sodium thioglycolate and 30 g/L of either A) NZ-Soy B) NZ-Soy BL4 C) NZ-Soy BL7 D) Phytone peptone E) BHI G) Tryptone.

1055 

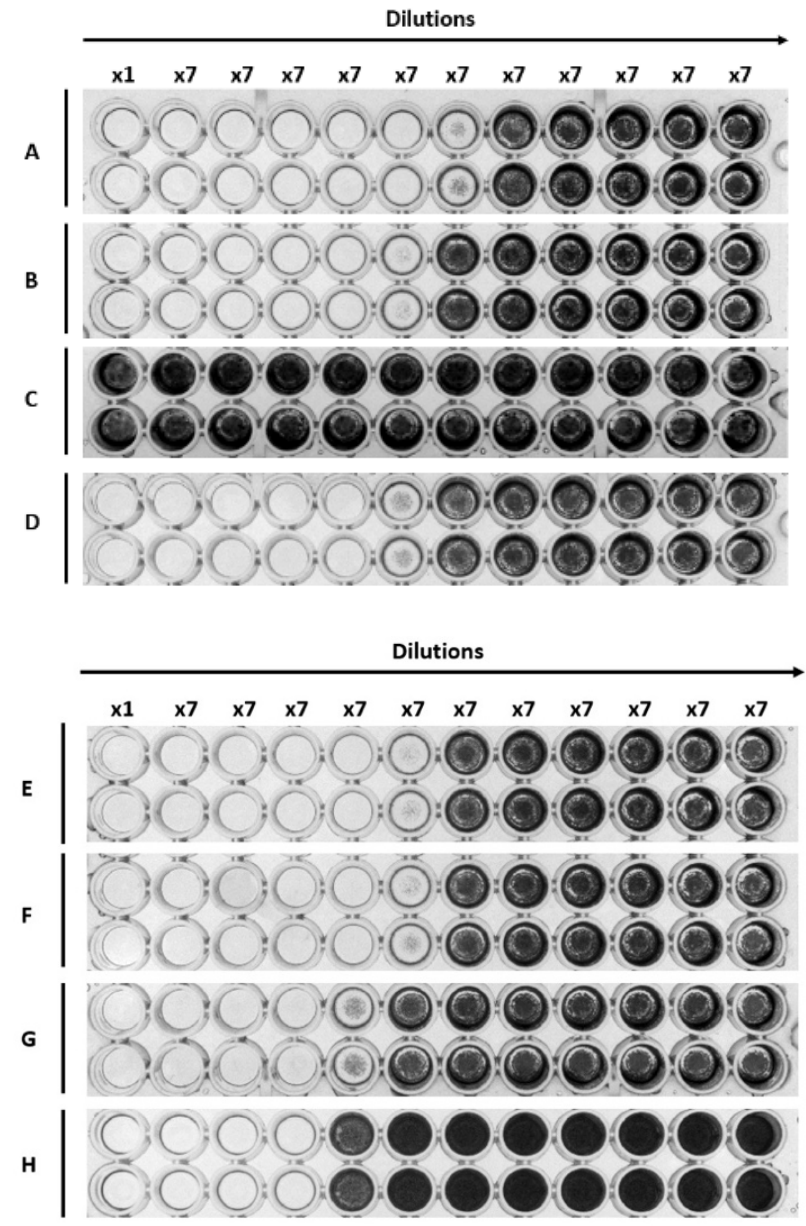

Dilutions

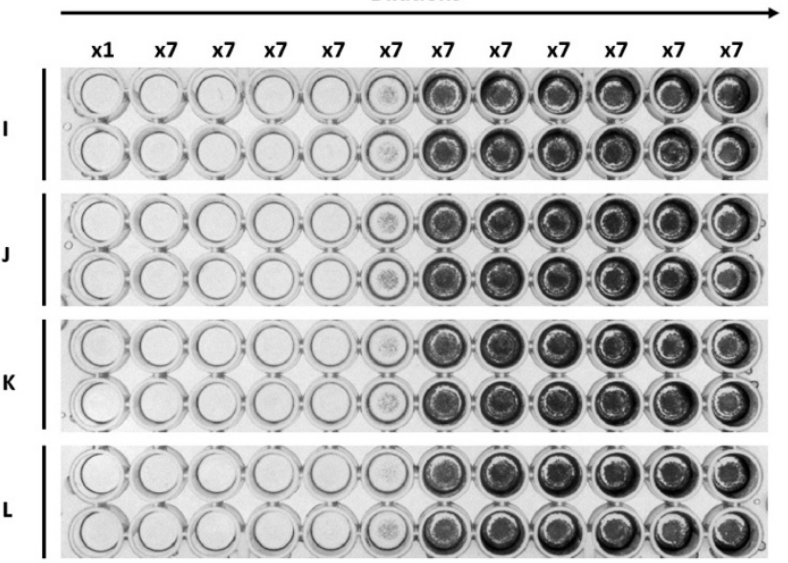

Fig. S5. In vitro cytotoxicity on Vero cells of TedA detoxified by MCO using different metal ions. Plates were stained with crystal violet after $48 \mathrm{~h}$ incubation and photographed to visualize cell survival in each well with black stain. All samples were tested as duplicates and consisted of $3.2 \mu \mathrm{g}$ MCO-detoxified TcdA added to first column, and serially diluted horizontally. All samples were incubated for $2 \mathrm{~h}$ at $37^{\circ} \mathrm{C}$ prior to cytotoxicity testing. All MCO samples were in $\mathrm{pH}$ 4.5. A) TcdA in pH 7.5 B) TcdA in $\mathrm{pH} 4.5$ C) TcdA $\mathrm{MCO}+\mathrm{CuCl}_{2}$ D) TcdA $\mathrm{MCO}+\mathrm{MgCl}_{2}$ E) TcdA $\left.\left.\left.\mathrm{MCO}+\mathrm{CoCl}_{2} \mathbf{F}\right) \mathrm{TcdA} \mathrm{MCO}+\mathrm{MnCl}_{2} \mathbf{G}\right) \mathrm{TcdA} \mathrm{MCO}+\mathrm{Fe}_{2}\left(\mathrm{SO}_{4}\right)_{3} \mathbf{H}\right) \mathrm{TcdA} \mathrm{MCO}+\mathrm{FeSO}_{4}$ I) TcdA MCO $+\mathrm{CaCl}_{2}$ J) $\mathrm{TcdA} \mathrm{MCO}+\mathrm{LiCl} \mathbf{K}) \mathrm{TcdA} \mathrm{MCO}+\mathrm{NiCl}_{2} \mathbf{L}$ ) TcdA $\mathrm{MCO}+\mathrm{AgNO}_{3}$. 


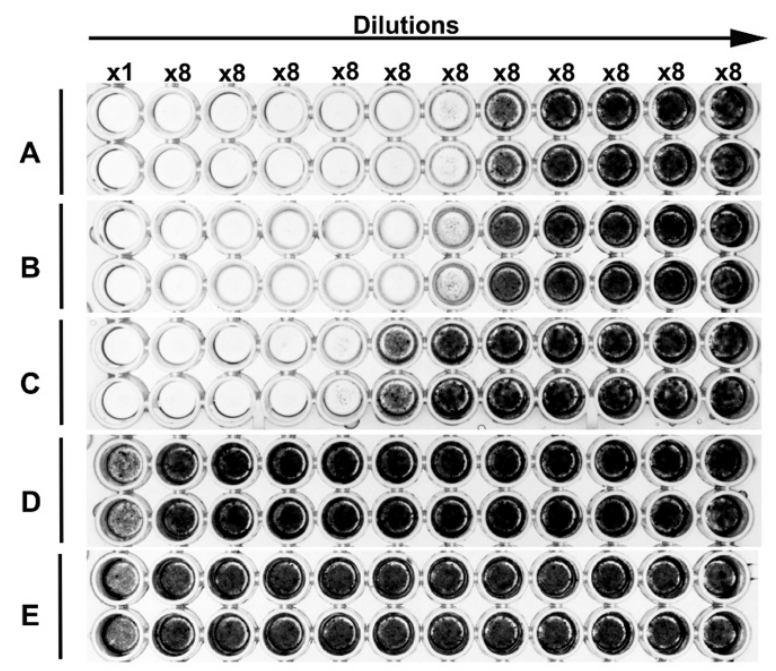

1060

1061

1062

1063

1064

1065

\section{6}

1067

Fig. S6. In vitro cytotoxicity on Vero cells of native and MCO-detoxified TedA. Plates were stained with crystal violet after $48 \mathrm{~h}$ incubation and photographed to visualize cell survival in each well with black stain. All samples were tested as duplicates and consisted of $3.7 \mu \mathrm{g}$ native or MCO-detoxified TcdA added to the first column and serially diluted horizontally. All samples were incubated for $2 \mathrm{~h}$ at $37^{\circ} \mathrm{C}$. A) Native TcdA in $\mathrm{pH} 7.5$ B) MCO-detoxified TcdA in pH 7.5 C) Native TcdA in $\mathrm{pH} 4.5$ D) MCO-detoxified TcdA in $\mathrm{pH} 4.5$ E) MCO-detoxified TcdA in $\mathrm{pH} 4.5$ re-adjusted to pH 7.5 .

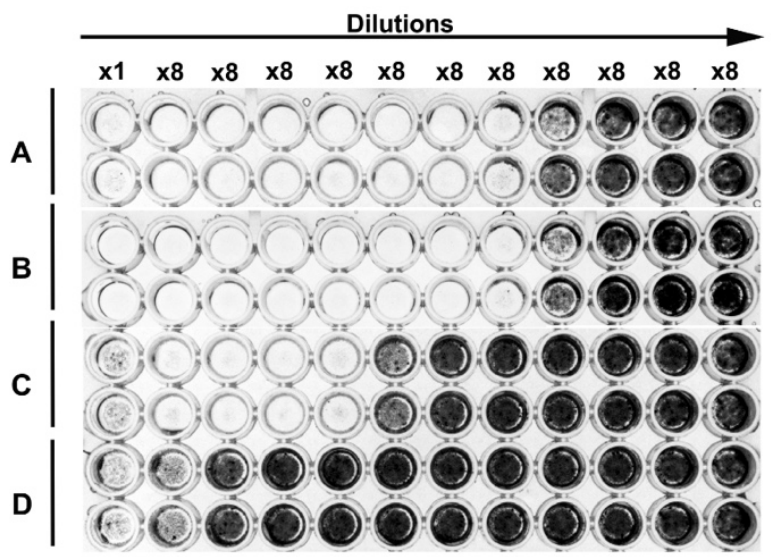

Fig. S7. In vitro cytotoxicity on Vero cells of native and MCO-detoxified TcdB. Plates were stained with crystal violet after $48 \mathrm{~h}$ incubation and photographed to visualize cell survival in each well with black stain All samples were tested as duplicates and consisted of $2.2 \mu \mathrm{g}$ native or MCO-detoxified TcdB added to the first column and serially diluted horizontally. All samples were incubated for $2 \mathrm{~h}$ at $37^{\circ} \mathrm{C}$. A) Native TcdB in $\mathrm{pH} 7.5 \mathrm{~B}$ ) MCO-detoxified TcdB in pH 7.5, 


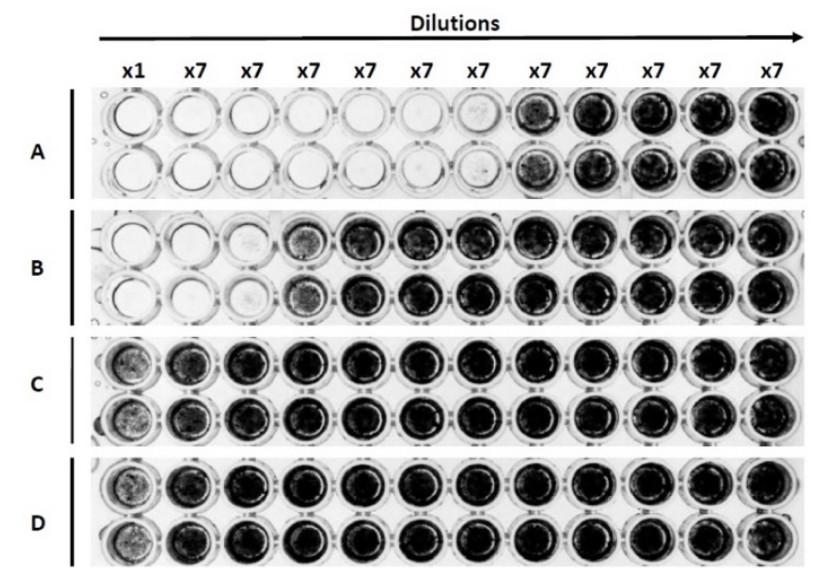

1076 Fig. S8. In vitro cytotoxicity on Vero cells of TedA detoxified by MCO at varying temperatures. Plates were 1077 stained with crystal violet after $48 \mathrm{~h}$ incubation and photographed to visualize cell survival in each well with black 1079 stain. All samples were tested as duplicates and consisted of $3.2 \mu \mathrm{g}$ TcdA added to the first column and serially diluted 1080 horizontally. All samples were incubated for $90 \mathrm{~min}$. A) Native TcdA in pH 7.5, B) MCO-detoxified TcdA $25^{\circ} \mathrm{C}, \mathbf{C}$ ) 1081 


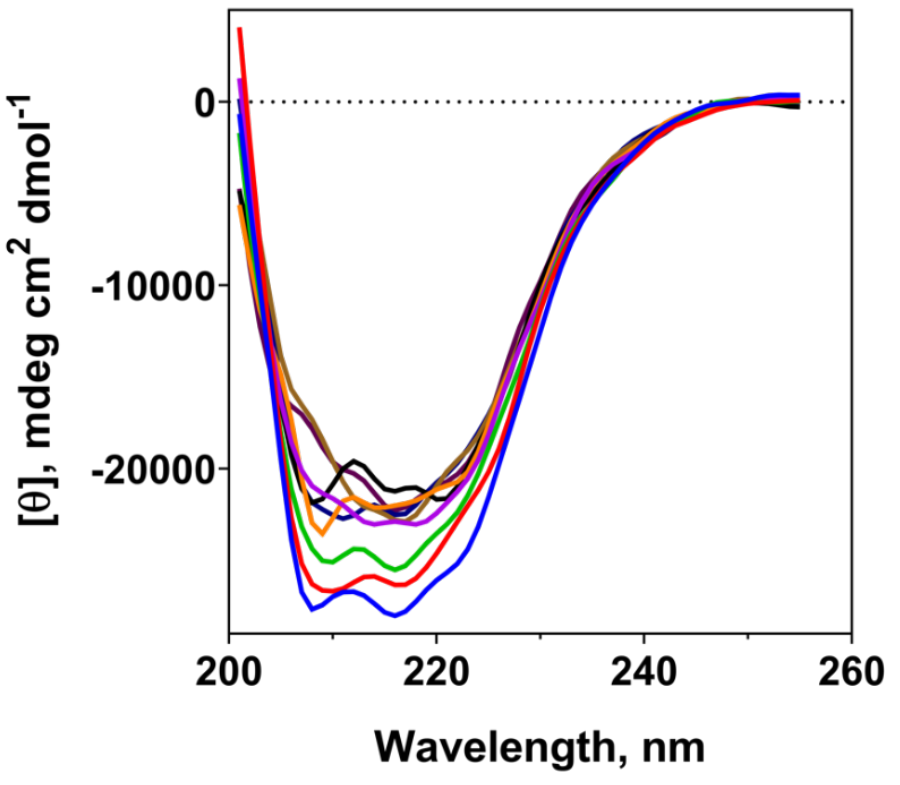

1083 Fig. S9. Far-UV circular dichroism analysis of the structural effect of MCO detoxification on TcdA. All samples 1084 are shown as an average of duplicate measurements with the buffer spectrum (blank) subtracted. The sample consisted of $0.65 \mu \mathrm{M}$ TcdA. Far-UV spectra ranging from $200-255 \mathrm{~nm}$. Blue: Native TcdA pH $4.50 .1 \mathrm{~min}$, red: TcdA MCO 0.1

1086 min, green: TcdA MCO 3 min, purple: TcdA MCO 6 min, orange: TcdA MCO 9 min, black: TcdA MCO 12 min, brown:

1087 TcdA MCO 15 min, dark blue: TcdA MCO 18 min, magenta: TcdA MCO 21 min. 


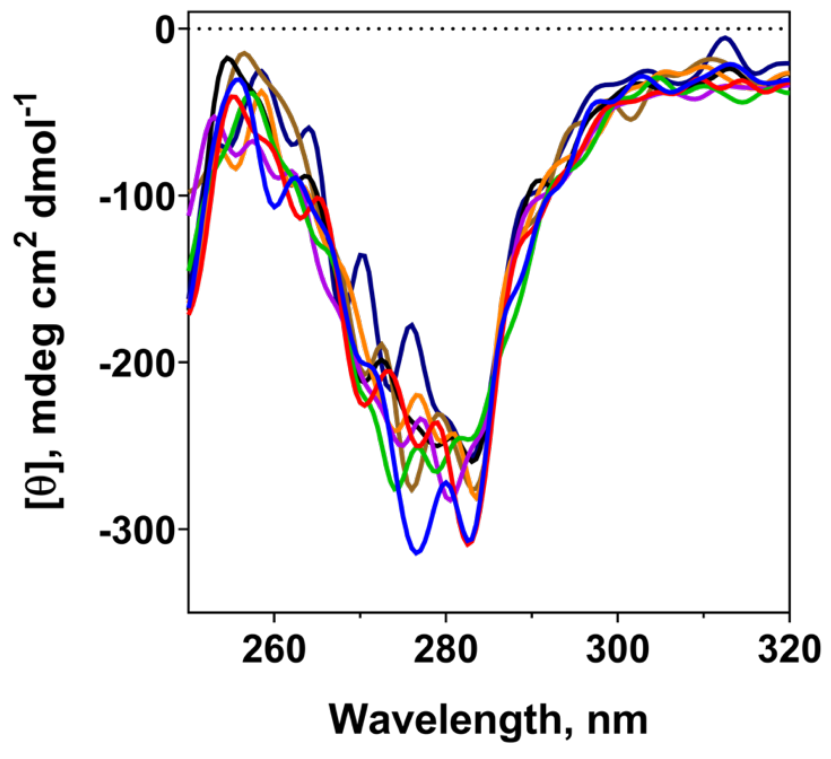

1090 Fig. S10. Near-UV circular dichroism analysis of the structural effect of MCO detoxification on TcdA. All samples are shown as an average of duplicate measurements with the buffer spectrum (blank) subtracted. Sample consisted of 3.25 $\mu \mathrm{M}$ TcdA. Near-UV spectra ranging from $250-320 \mathrm{~nm}$. Blue: TcdA MCO $0.1 \mathrm{~min}$, red: TcdA MCO $3 \mathrm{~min}$, green: TcdA MCO 6 min, purple: TcdA MCO 9 min, orange: TcdA MCO 12 min, black: TcdA MCO 15 min, brown: TcdA MCO 18 min, dark blue: TcdA MCO 21 min. 
1096 Table S1. Molar ratios and experimental conditions used for the MCO pilot study on TcdA.

\begin{tabular}{|c|c|c|c|c|c|}
\hline \multirow[t]{2}{*}{ Samples } & \multicolumn{3}{|c|}{ Final concentrations in reaction mixture $(\mu \mathrm{M})$} & \multirow{2}{*}{$\begin{array}{c}\text { Molar ratios } \\
\left(\operatorname{TcdA}: \mathrm{Cu}^{2+}: \mathrm{H}_{2} \mathrm{O}_{2}\right)\end{array}$} & \multirow{2}{*}{$\begin{array}{c}\mathrm{pH} \\
\text { (tested at all pH) }\end{array}$} \\
\hline & TedA & $\mathrm{CuCl}_{2}$ & $\mathrm{H}_{2} \mathrm{O}_{2}$ & & \\
\hline Condition 1 & 0.5 & 15 & 50 & $1: 30: 100$ & $4,4.5,5,7.5^{*}$ \\
\hline Condition 2 & 0.5 & 15 & 250 & 1:30:500 & $4,4.5,5,7.5$ \\
\hline Condition 3 & 0.5 & 15 & 500 & $1: 30: 1000$ & $4,4.5,5,7.5$ \\
\hline Condition 4 & 0.5 & 30 & 50 & 1:60:100 & $4,4.5,5,7.5$ \\
\hline Condition 5 & 0.5 & 30 & 500 & $1: 60: 1000$ & $4,4.5,5,7.5$ \\
\hline Condition 6 & 0.5 & 37.5 & 250 & $1: 75: 500$ & $4,4.5,5,7.5$ \\
\hline Condition 7 & 0.5 & 37.5 & 500 & $1: 75: 1000$ & $4,4.5,5,7.5$ \\
\hline Condition 8 & 0.5 & 37.5 & 1000 & $1: 75: 2000$ & $4,4.5,5,7.5$ \\
\hline
\end{tabular}

$*=$ All four $\mathrm{pH}$ values were tested for each condition.

1097 